\title{
Narrative Review: Bioactive Potential of Various Mushrooms as the Treasure of Versatile Therapeutic Natural Product
}

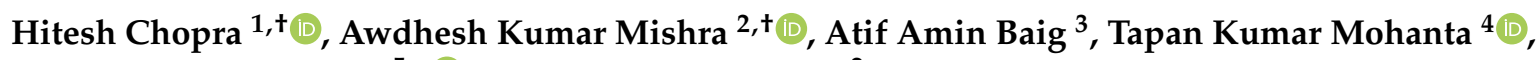 \\ Yugal Kishore Mohanta ${ }^{5, *}$ and Kwang-Hyun Baek ${ }^{2, *}$ \\ 1 Chitkara College of Pharmacy, Chitkara University, Punjab 140401, India; chopraontheride@gmail.com \\ 2 Department of Biotechnology, Yeungnam University, Gyeongsan 38541, Gyeongsangbuk-do, Korea; \\ awadhesh.biotech07@gmail.com \\ 3 Unit of Biochemistry, Faculty of Medicine, Universiti Sultan Zainal Abidin, Kuala Terengganu 20400, \\ Malaysia; atifamin@unisza.edu.my \\ 4 Natural and Medical Sciences Research Centre, University of Nizwa, Nizwa 616, Oman; \\ tapan.mohanta@unizwa.edu.om \\ 5 Department of Botany, Maharaja Sriram Chandra Bhanj Deo University, Baripada 757003, India \\ * Correspondence: ykmohanta@gmail.com (Y.K.M.); khbaek@ynu.ac.kr (K.-H.B.) \\ + These authors contributed equally.
}

check for updates

Citation: Chopra, H.; Mishra, A.K.; Baig, A.A.; Mohanta, T.K.; Mohanta, Y.K.; Baek, K.-H. Narrative Review: Bioactive Potential of Various Mushrooms as the Treasure of Versatile Therapeutic Natural Product. J. Fungi 2021, 7, 728. https://doi.org/10.3390/jof7090728

Academic Editors: Jasmina Glamočlija and Dejan Stojković

Received: 3 August 2021

Accepted: 2 September 2021

Published: 6 September 2021

Publisher's Note: MDPI stays neutral with regard to jurisdictional claims in published maps and institutional affiliations.

Copyright: (c) 2021 by the authors. Licensee MDPI, Basel, Switzerland. This article is an open access article distributed under the terms and conditions of the Creative Commons Attribution (CC BY) license (https:// creativecommons.org/licenses/by/ $4.0 /)$.

\begin{abstract}
Mushrooms have remained an eternal part of traditional cuisines due to their beneficial health potential and have long been recognized as a folk medicine for their broad spectrum of nutraceuticals, as well as therapeutic and prophylactic uses. Nowadays, they have been extensively investigated to explain the chemical nature and mechanisms of action of their biomedicine and nutraceuticals capacity. Mushrooms belong to the astounding dominion of Fungi and are known as a macrofungus. Significant health benefits of mushrooms, including antiviral, antibacterial, antiparasitic, antifungal, wound healing, anticancer, immunomodulating, antioxidant, radical scavenging, detoxification, hepatoprotective cardiovascular, anti-hypercholesterolemia, and anti-diabetic effects, etc., have been reported around the globe and have attracted significant interests of its further exploration in commercial sectors. They can function as functional foods, help in the treatment and therapeutic interventions of sub-optimal health states, and prevent some consequences of lifethreatening diseases. Mushrooms mainly contained low and high molecular weight polysaccharides, fatty acids, lectins, and glucans responsible for their therapeutic action. Due to the large varieties of mushrooms present, it becomes challenging to identify chemical components present in them and their beneficial action. This article highlights such therapeutic activities with their active ingredients for mushrooms.
\end{abstract}

Keywords: anti-HIV; immunomodulatory; antioxidant; hepatoprotective; anti-inflammatory

\section{Introduction}

Mushrooms have been present on earth for ages and are an important, indispensable part of global cuisine. Along with this, mushrooms are exploited for their beneficial health properties. There are about 2000 mushroom species worldwide, but just a handful are edible or nutraceutical. Agaricus bisporus is the most widely grown mushroom, followed by Lentinus edodes and Flammulina velutipes. Mushrooms contain various metabolites, such as terpenes, steroids, anthraquinone, phenolic acid, and benzoic acid, while primary metabolites contain proteins, oxalic acid, and peptides. Mushrooms have been reported to have an action against both Gram-positive and Gram-negative bacteria [1].

Nutritionally, they are rich in protein and amino acids but lack fatty acid content [2]. However, they contain a significant amount of vitamins such as B1, B2, B12, C, D, and E [3-8]. Thus, they act as the perfect source of present nutrition and promote the health for synergistic effects of present bioactive compounds. Structurally, mushrooms comprise 
the pileus, lamella, stipe, mycelium, and roots. The roots are mainly responsible for absorbing and gathering nutrients [9]. Earlier, there was a misconception regarding the classification of mushrooms as plants. Later, with advancement in science, they were added under the independent kingdom known as Mycota, mainly characterized by chitin inside the cell walls. Globally, various regulatory agencies have approved their use as dietary supplements such as the National Institute of Health, Food for Specific Health Use, National Health Service, etc. The purpose of this article is to curate and review the tremendous benefits and varieties of various mushrooms, unveiling their use at a broad scale to be resource-able for future therapeutic usage. These mushrooms include edible though they can be medicinal.

\section{Pharmacological Actions of Mushroom}

\subsection{Mushrooms and Wound Healing}

For ages, mushrooms have been shown to have the potential for wound healing application. Wound healing is a complex phenomenon, requiring nutrition and a moist environment for speeding up wound healing. The Auricularia auricula-judge, a type of medicinal mushroom, has been beneficial for wound healing [10]. The mushroom acts via the promotion of fibroblasts and keratinocytes and acts as a catalyst for collagen synthesis during wound healing. The extract could show dose-dependent wound healing activity. The extract reduces the expression of E-cadherin, causing the down-regulation. The downregulation handles the wound healing effect, as suggested by other researchers as well.

Many other mushrooms have been shown to possess the wound healing action via the formation of ROS. The level of ROS decides the speed of the wound healing process. The low levels of ROS activate the wound healing process; however, higher levels of ROS handle the detoxification, causing cellular damage [11]. The wound healing activity is regulated via the balance between the pro-inflammatory and pro-regenerative signals regulated via cytokines. The polysaccharides derived from the Gracilaria lemaneiformis also speed up the wound closure rate, thus improving the epithelial layer thickness and collagen deposition [12]. As figured out through the Edu assay, the polysaccharide fraction significantly increased the DNA content during the S-phase. It was also found that the EdU positive was observed near the woundless area and the wound area [12]. Regulating the wound healing activity by increasing the cell proliferation causes accelerated wound healing [13]. The fraction could also activate the PI3K/PKC (Phosphatidylinositol 3Kinase/Protein kinase) signaling pathway. Jesus et al. evaluated the wound healing effect of a $\beta$-D-glucan from the edible mushroom Piptoporus betulinus [14]. They found that the $\beta$-D-glucan derived showed promotion of viability of caco- 2 cells confirmed by MTT (3-(4,5-dimethylthiazol-2-yl)-2,5-diphenyl-2H-tetrazolium bromide) assay. It was also seen that the polysaccharide derived from mushrooms sped up the in vitro wound healing process via migration of epithelial intestinal cell migration.

Rao et al. coupled the zinc nanoparticles with the chitosan derived from the mushroom Agaricus Bisporus, Aspergillus Niger [15]. The chitosan acted as a capping material at zinc nanoparticles. The $500 \mu \mathrm{g}$ of nanoparticles could cause an $83 \%$ and $81 \%$ reduction in skin fibroblasts and keratinocyte cell viability and showed excellent biocompatibility towards the skin cells. Because of zinc nanoparticles, the complex showed antibacterial action on Staphylococcus aureus. The Beta-glucan content derived from mushroom Sparassis crispa showed wound healing action on diabetic wounds [16]. Researchers evaluated the effect of medicinal mushroom Sparassis crispa on the diabetes-induced animal model. The administration of mushrooms resulted in a faster mechanism of wound healing compared to the standard control group. The population of infiltrating neutrophils increased as the mushroom was administered. The immuno-histochemical staining confirmed the migration of macrophages. The presence of mushroom extract also resulted in the expression of TGF1 in the subcutaneous dermal layer. Moreover, the results of the Azan Mallory staining confirmed the collagen regeneration in the wound area. Many researchers have also reported the wound healing potential of mushrooms, as presented in Table 1. 
Table 1. Medicinal mushrooms have wound-healing properties.

\begin{tabular}{|c|c|c|c|c|}
\hline $\begin{array}{l}\text { Name of } \\
\text { Mushroom }\end{array}$ & In-Vivo & In-Vitro & Outcome of Study & References \\
\hline $\begin{array}{l}\text { Coriolus } \\
\text { versicolor and } \\
\text { Boletus edulis }\end{array}$ & - & $\begin{array}{l}\text { Cell lines: MCF-7, breast cancer } \\
\text { cell lines; HT-29, human colorectal } \\
\text { cancer cell line; HUH-7, human } \\
\text { hepatoma cell lines; } \\
\text { Antibacterial: (Pseudomonas } \\
\text { aeruginosa, Klebsiella pneumonia, } \\
\text { Staphylococcus aureus, and } \\
\text { Enterococcus faecalis) and } \\
\text { Antifungal (Candida albicans and } \\
\text { Candida utilis). } \\
\text { L929, murine fibroblast cell line. }\end{array}$ & $\begin{array}{l}\text { The silver nanoparticles } \\
\text { synthesized from mushrooms } \\
\text { showed anticancer properties } \\
\text { The silver nanoparticles } \\
\text { synthesized from mushrooms } \\
\text { showed anticancer properties } \\
\text { The silver nanoparticles } \\
\text { synthesized from mushroom } \\
\text { showed wound healing }\end{array}$ & [17] \\
\hline $\begin{array}{l}\text { Agaricus } \\
\text { bisporus }\end{array}$ & - & Human ocular fibroblasts & $\begin{array}{c}\text { Use of Agaricus bisporus results } \\
\text { in wound healing in a } \\
\text { dose-dependent manner. }\end{array}$ & [18] \\
\hline Agaricus blazei & $\begin{array}{l}\text { Induced } \\
\text { burn-wound-treated } \\
\text { rats }\end{array}$ & - & $\begin{array}{l}\text { The use of Agaricus blazei in the } \\
\text { treatment of burns wounds } \\
\text { induces the expression of IL-1 } \\
\text { mRNA and increases the } \\
\text { accumulation of macrophages in } \\
\text { the wound area. }\end{array}$ & [19] \\
\hline $\begin{array}{l}\text { Agaricus } \\
\text { Sylvaticus }\end{array}$ & Rats with wound & - & $\begin{array}{l}\text { Phenolic component of } \\
\text { mushroom was found associated } \\
\text { to the wound healing properties }\end{array}$ & [20] \\
\hline $\begin{array}{l}\text { Phanerochaete } \\
\text { chrysosporium }\end{array}$ & - & $\begin{array}{l}\text { NIH 3T3, Murine Embryonic } \\
\text { Fibroblast cell lines }\end{array}$ & $\begin{array}{l}\text { Prepared curcumin loaded } \\
\text { mycelium-based film capable of } \\
\text { curing the injured tissue }\end{array}$ & [21] \\
\hline $\begin{array}{l}\text { Ganoderma } \\
\text { lucidum }\end{array}$ & $\begin{array}{c}\text { Indomethacin } \\
\text { induced gastric } \\
\text { mucosal lesions in rats }\end{array}$ & - & $\begin{array}{c}\text { Polysaccharide fraction causes } \\
\text { the healing of peptic ulcers in } \\
\text { rats }\end{array}$ & [22] \\
\hline $\begin{array}{l}\text { Ganoderma } \\
\text { lucidum }\end{array}$ & $\begin{array}{l}\text { Sprague-Dawley rats } \\
\text { induced with wound }\end{array}$ & - & $\begin{array}{l}\text { Accelerated wound healing in } \\
\text { rat liver tissues after Monopolar } \\
\text { Electrosurgery }\end{array}$ & [23] \\
\hline Sparassis crispa & $\begin{array}{c}\text { Streptozotocin } \\
\text { induced diabetic mice }\end{array}$ & - & $\begin{array}{l}\text { Wound healing activity was } \\
\text { observed on topical application } \\
\text { of Sparassis crispa extract on } \\
\text { wound }\end{array}$ & [24] \\
\hline $\begin{array}{l}\text { Hericium } \\
\text { erinaceus }\end{array}$ & $\begin{array}{l}\text { Male Sprague-Dawley } \\
\text { rats induced with } \\
\text { wound }\end{array}$ & - & $\begin{array}{c}\text { Topical application of an } \\
\text { aqueous extract of Hericium } \\
\text { erinaceus showed wound healing } \\
\text { action in rats }\end{array}$ & [25] \\
\hline $\begin{array}{l}\text { Phellinus } \\
\text { gilvus }\end{array}$ & $\begin{array}{c}\text { Streptozotocin } \\
\text { induced diabetic rats }\end{array}$ & - & $\begin{array}{c}\text { Isolated polysaccharides showed } \\
\text { wound healing action }\end{array}$ & [26] \\
\hline $\begin{array}{c}\text { Dioscorea } \\
\text { batatas Decne }\end{array}$ & - & INT-407 cells & $\begin{array}{l}\text { The phytoglycoprotein isolated } \\
\text { showed wound healing action at } \\
\text { the intestinal epithelial wound }\end{array}$ & [27] \\
\hline $\begin{array}{l}\text { Flammulina } \\
\text { velutipes }\end{array}$ & $\begin{array}{c}\text { Female } \\
\text { Sprague-Dawley rat }\end{array}$ & - & $\begin{array}{l}\text { Flammulina velutipes } \\
\text { polysaccharides scaffold showed } \\
\text { skin wound healing and hair } \\
\text { follicle regenerative action }\end{array}$ & [28] \\
\hline
\end{tabular}


Table 1. Cont.

\begin{tabular}{|c|c|c|c|c|}
\hline $\begin{array}{c}\text { Name of } \\
\text { Mushroom }\end{array}$ & In-Vivo & In-Vitro & Outcome of Study & References \\
\hline $\begin{array}{l}\text { Schizophyllum } \\
\text { commune }\end{array}$ & NA & L929 fibroblasts cells & $\begin{array}{l}\text { Electrospunned fiber with } \\
\text { polyvinyl alcohol showed } \\
\text { improved wound healing and } \\
\text { promoted the migration of cells } \\
\text { at the wound site }\end{array}$ & [29] \\
\hline $\begin{array}{l}\text { Lignosus } \\
\text { rhinocerotis }\end{array}$ & NA & Human dermal cells & $\begin{array}{l}\text { Gold nanoparticles synthesized } \\
\text { with the mushroom extract and } \\
\text { chitosan showed wound healing } \\
\text { capability though non-cytotoxic }\end{array}$ & {$[30]$} \\
\hline
\end{tabular}

\subsection{Mushrooms in Anti-HIV Action}

Mushrooms have also been reported to target HIV. Mushrooms such as Agaricus sylvaticus reduce the oxidative stress in HIV-infected patients [31]. Administration with the supplementation containing the mushroom extract showed improved antioxidant defense in the infected individual. A reduction in TBARS (Thiobarbituric acid reactive substance; a method used to detect lipid peroxidation) and an increase by NN values in DPPH (2,2-Diphenyl-1-picrylhydrazyl) and Trolox equivalent capacity were reported in HIV-positive patients. The supplementation causes reversed oxidative alterations and improvement in antioxidant defense and can be used as a complementary strategy for the patients. Researchers administered the patients with the nutrients derived from the Alternanthera pungens to the asymptomatic HIV-positive patients. It was seen that there was a significant decrease in the marker TBARS, and a rise in the number of $\mathrm{CD} 4^{+}$and $\mathrm{CD} 8^{+} \mathrm{T}$ cells was observed [32]. Many other mushrooms, such as P. abalonus, Coriolus versicolor, A bisporus, P. citrinopileatus, L. edodes, have been reported to possess anti-HIV action [33-37].

A marketed formulation known as Immune Assist 24/7 has constituents derived from mushrooms [38]. It has components that have immunomodulating and antiviral properties. In clinical trials conducted in Ghana, it was found that administering $800 \mathrm{mg}$ of tablets of Immune Assist 24/7, once daily, increased $\mathrm{CD}^{+} \mathrm{T}$ lymphocytes. In one of the cases, the increase in $\mathrm{CD}^{+} \mathrm{T}$ cells showed a $4000 \%$ increase in 60 days. The laccase enzyme produced by the Ganoderma spp. and Lentinus spp. have been reported to possess the property to inhibit the reverse transcriptase of HIV [39]. Flow cytometry results showed that the extracts of mushrooms showed over $50 \%$ inhibition for viral replication. The enzymatic extract from the Lentinus spp. showed an $86.4 \%$ inhibition rate at a concentration of $2466 \mathrm{U} / \mathrm{L}$. The inhibition efficiency was higher, but it was lower than the antiretroviral therapy drug AZT (98\%). The efficiency was compared with two batches taken from the same species, but variation was observed. The laccases are derived from the Coprinus comatus mushroom. The derived component of mushroom showed anti-HIV-1 RT activity against the $\mathrm{IC}_{50}$ values of $5.85 \mu \mathrm{M}$ [40]. The lectins derived from the Agaricus bitorquis also showed to possess the anti-HIV nature [41]. The lectins showed anti-HIV-1 reverse transcriptase activity at a $\mathrm{IC}_{50}$ value of $4.69 \mu \mathrm{M}$, which was more effective than A. bisporus with a $\mathrm{IC}_{50}$ value of $8 \mu \mathrm{M}$ [35].

Sillapachaiyaporn et al. studied the effect of Auricularia polytricha on HIV-1 [42]. AntiHIV-1 protease activity of the isolated compounds from hexane crude extracts of Auricularia polytricha (APH) [(Linoleoyl oleoyl palmitoylglycerol, Linoleoyl oleoyl stearoylglycerol, Distearoyl palmitoylglycerol, Linoleic acid, Ergosterol) Table S1]. These compounds, such as Ergosterol, Linoleic acid, Distearoylpalmitoylglycerol, acted unitedly for the inhibition. They made this evidenced by the low solubility of ergosterol in water. When combined with all other components, their activity increased (for chemical structures, refer to Figure 1). El-Mekkawy et al. reported the role of Ganoderiol F, ganodermanontriol as anti-HIV agents [43]. Moreover, other compounds such as ganoderic acid B, ganoderiol B, ganoderic acid C1, $3 \beta$-5 $\alpha$-dihydroxy- $6 \beta$-methoxyergosta-7,22-diene, ganoderic acid $\alpha$, ganoderic 
acid $\mathrm{H}$, and ganoderiol A showed mild inhibition activity towards the HIV-1 PR. Similarly, El-Dine et al. reported isolating new triterpenes, such as colorssolactone V, Colossolactone VI, Colossolactone VII, and Colossolactone VIII, from the Ganoderma colossum, showing antiHIV activity [44]. Hui et al. reported the isolation of hemolysin from the edible mushroom Pleurotus nebrodensis, using chromatography techniques [45]. The molecule Nebrodeolysin has a molecular weight of $27 \mathrm{kDa}$. In vivo studies showed hemolytic activity against the rabbit erythrocytes and caused the efflux of potassium ions. The compound could induce cytotoxicity against the L929 and HeLa cells, as evidenced by microscopic observations and DNA ladder, respectively.

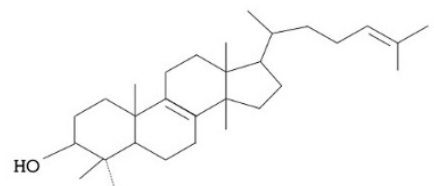

Lanosterol

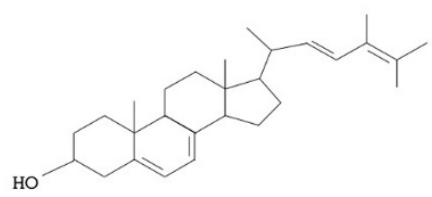

Ergosterol

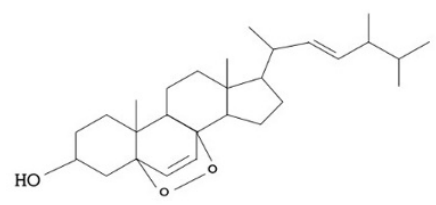

Ergosterol peroxide

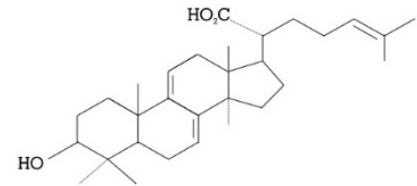

7,9(11),24-Lanostatriene-3ß-21-diol

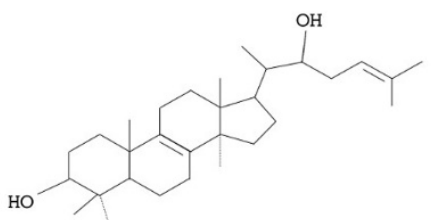

Inotodiol

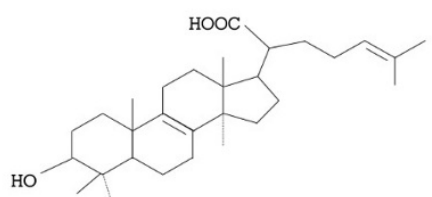

Trametenolic acid

Figure 1. Active phytochemicals derived from mushrooms having the anticancer effect.

Edible mushroom Pholiota adiposa showed constituents with antioxidant and anti-HIV activities [46]. The compound HEB showed antioxidant potency, DPPH radical activity. The compound could show the inhibition of HIV-1 replication in the TZM-BL cells infected by the pseudovirus. The compound showed the inhibition of the viral entry process and enzymes required to enter the HIV-1 life cycle. The HEB showed inhibition of reverse transcriptase and integrase activities, which was high compared to pepstatin A. Many other researchers also reported anti-HIV action of mushrooms and their constituents, as shown in Table 2. 
Table 2. Mushrooms and their active constituents for the anti-HIV.

\begin{tabular}{|c|c|c|c|}
\hline Name of Mushroom & Active Constituent & Anti-HIV Activity against & References \\
\hline Russula paludosa & Fraction SU2 & HIV-1 RT & [47] \\
\hline Agaricus bitorquis & Agaricus bitorquis Lectin & HIV-1 RT and leukemic cells & [41] \\
\hline Lignosus rhinocerus & $\begin{array}{c}\text { heliantriol F and } 6 \\
\alpha \text {-fluoroprogesterone }\end{array}$ & $\begin{array}{l}\text { HIV-1 protease inhibitor; inhibition of HIV-1 } \\
\text { induced syncytial formation and p24 } \\
\text { production in the infected MOLT- } 4 \text { cells. }\end{array}$ & [48] \\
\hline Ganoderma colossum & Ganomycin I, Ganomycin B & HIV-1 protease & [49] \\
\hline Cordyceps sobolifera & Cordysobin & HIV-1 RT & [50] \\
\hline Fomes fomentarius & $\begin{array}{l}\text { Water-soluble melanin-glucan } \\
\text { complex; insoluble } \\
\text { chitin-glucan-melanin } \\
\text { complex }\end{array}$ & HIV-1 protease & [51] \\
\hline A. subrufescens & $\beta$-glucan & HIV-1 RT & [52] \\
\hline A. subrufescens & Laccase & HIV-1 RT & [53] \\
\hline A. subrufescens & Lectin & HIV-1 RT & [54] \\
\hline Inonotus obliquus & Terpenes & HIV-1 RT & [55] \\
\hline I. obliquus & Polysaccharides & HIV-1 RT & [56] \\
\hline I. obliquus & Terpenes & HIV-1 RT & [57] \\
\hline I. obliquus & Polyphenols & HIV-1 RT & [58] \\
\hline I. obliquus & Terpenes & HIV-1 RT & [59] \\
\hline Phellinus igniarius & Terpenes & HIV-1 RT & [60] \\
\hline Pleurotus abalonus & $\begin{array}{l}\text { Polysaccharide-peptide } \\
\text { complex LB-1b }\end{array}$ & HIV-1 RT & [36] \\
\hline Flammulina velutipes & Velutin & HIV-1 RT & [61] \\
\hline Hypsizigus marmoreus & Marmorin & HIV-1 RT & [62] \\
\hline Pleurotus citrinopileatus & Lectin & HIV-1 RT & [33] \\
\hline Russula delica & Dimeric lectin & HIV-1 RT & [34] \\
\hline Pleurotus ostreatus & Glycoprotein & HIV-1 RT & [63] \\
\hline Pholiota adiposa & Lectin & HIV-1 RT & [64] \\
\hline Agrocybe cylindracea & Agrocybin & HIV-1 RT & [65] \\
\hline Pleurotus cornucopiae & Laccase & HIV-1 RT & {$[66]$} \\
\hline Schizophyllum commune & 20-kDa ribonuclease & HIV-1 RT & [67] \\
\hline Lentinus edodes & Lentin & HIV-1 RT & [68] \\
\hline Hericium erinaceum & Lentin & HIV-1 RT & [69] \\
\hline Pleurotus abalonus & 120-kDa Polysaccharide & HIV-1 RT & [70] \\
\hline
\end{tabular}

\subsection{Mushrooms and Anticancer Potentials}

Cancer is one of the leading causes of death worldwide. The uncontrolled growth of cells can characterize as cancer and may be present in blood and body parts. Mushrooms have been reported to control the cell division, and, used in cancer therapy [71], such as the chaga mushroom (Inonotus obliquus), possess anti-cancerous compounds [72,73]. The main chemical constituents include lanosterol, 7,9(11),24-lanostatriene-3 $\beta$-21-diol, ergosterol, inotodiol, ergosterol peroxide, and trametenolic acid (mentioned in Figure 1); they showed anticancer activity counter to the prostatic carcinoma cell lines PC3 and breast cancer cell line MDA-MB-231. The compounds that showed $\mathrm{IC}_{50}$ values against PC3 were calculated to be $9.82 \pm 0.98 \mu \mathrm{g} / \mathrm{mL}$ for ergosterol, $38.19 \pm 1.67 \mu \mathrm{g} / \mathrm{mL}$ for ergosterol 
peroxide, $63.71 \pm 3.31 \mu \mathrm{g} / \mathrm{mL}$ for trametenolic acid, and $73.46 \pm 0.64 \mu \mathrm{g} / \mathrm{mL}$ for 7,9(11),24lanostatriene-3 $\beta$-21-diol. However, inotodiol and lanosterol were non-efficient with $\mathrm{IC}_{50}$ values above $100 \mu \mathrm{g} / \mathrm{mL}$, while Nakata et al. successfully isolated the inonotsuoxides A, inotodiol, trametenolic acid, and lanosterol from the same mushrooms and showed antitumor activity in vivo [74]. Park and his coworkers reported the isolation of proteins from the Cordyceps militaris (CMP). The isolated proteins showed trypsin-like serine protease activity. The protein could inhibit F. oxysporum and cytotoxicity towards the human breast and bladder cancer cells [75]. Kosanic et al. studied the effect of metal concentration on anticancer activity of Lactarius deliciosus and Macrolepiota procera [76]. The anticancer activity was determined on the HeLa cells, human lung carcinoma A545 cells, and human colon carcinoma LS174 cells. The study showed that the M. procera showed comprehensively better anticancer effects on the A549 and LS174 cell lines, while the HeLa cell lines were more prone to Lactarius deliciosus. Similarly, Kim et al. isolated the hetero polysaccharides from the L. deliciosus with anticancer activity [77].

Boobalan et al. prepared carbon dots derived from the oyster mushroom [78]. These can be used as colorimetric sensors for the quantification of $\mathrm{Pb}^{2+}$ ions. These dots can also be used as a fluorescent probe for DNA recognition through electrostatic interaction between the ctDNA and C-dots. These dots also showed anticancer activity against the MDA-MB-231 breast cancer cells. The presence of C-dots caused morphological changes in the cell blebbing and chromatin condensation. The Hoechst 33,342 staining of cancer cells confirmed the fragmentation of the nuclear region. The nanoparticles of selenium decorated with the water-soluble polysaccharides were extracted from the mushroom [79]. The nanoparticles were stable for 13 weeks and with a particle size of $91-102 \mathrm{~nm}$. The gastric adenocarcinoma cells were found to be more sensitive to nanoparticles. Nanoparticles induced the caspase and mitochondria-mediated apoptosis.

Similarly, the polysaccharides (HLP-1-1 and HLP-2-1) derived from Helvella leucopus showed anticancer activity against the HepG2 cells [80]. The secondary metabolites of Ganoderma applanatum were effective against the human colon cancer cell lines (Caco-2) [81]. The metabolites caused morphological alterations and an increase in levels of glutathione. Moreover, the levels of the Bax/Bcl-2 ratio increased significantly with the treatment of metabolites. The in vivo study showed a reduction in solid Ehrlich tumor mass after 5 days of exposure to metabolites. Researchers studied the ethanol extract of Marasmius oreades on the HT-29, MCF-7, and MDA-MB-231 cells by using MTT assay [82]. Anticancer activities of mushroom extract of other researchers have been cited in Table 3.

Table 3. Mushrooms have anticancer properties.

\begin{tabular}{|c|c|c|c|c|}
\hline S1. No. & Name of Mushroom & Tested Chemical Constituent & Cell Lines Studied & References \\
\hline 1 & Flammulina velutipes & Water extract & BT-20, MCF-7 and MDA-MB-231 & [83] \\
\hline 2 & F. velutipes & Flammulinolide A, B, C, and F & Hela, HepG2 and KB cells & [84] \\
\hline 3 & F. velutipes & $\begin{array}{l}\text { Enokipodin B, D, and J, } \\
\text { 2,5-cuparadiene-1,4-dione }\end{array}$ & $\begin{array}{l}\text { HepG2, MCF-7, A549, and } \\
\text { SGC7901 }\end{array}$ & [85] \\
\hline 4 & F. velutipes & Alkaline-soluble polysaccharide & SC-180 mouse model & [86] \\
\hline 5 & F. velutipes & Polysaccharides & $\begin{array}{l}\text { S-180 mice tumor model and } \\
\text { SMMC-7721 human hepatoma } \\
\text { cells }\end{array}$ & [87] \\
\hline 6 & F. velutipes & Polysaccharide & BEL-7402 cell & [88] \\
\hline 7 & F. velutipes & $\begin{array}{c}\text { Ergosterol, and 22, } \\
\text { 23-dihydroergosterol }\end{array}$ & SGC, HepG2, A549, and U251 & [89] \\
\hline 8 & F. velutipes & Proflamin & $\begin{array}{l}\text { B-16 melanoma and Ca755 } \\
\text { adenocarcinoma }\end{array}$ & [90] \\
\hline
\end{tabular}


Table 3. Cont.

\begin{tabular}{|c|c|c|c|c|}
\hline Sl. No. & Name of Mushroom & Tested Chemical Constituent & Cell Lines Studied & References \\
\hline 9 & $\begin{array}{l}\text { Ganoderma } \\
\text { neo-japonicum }\end{array}$ & Ethanolic extract & Human colonic carcinoma cells & [91] \\
\hline 10 & Astraeus hygrometricus & Astrakurkurone & Hep 3B and Hep G2 & [92] \\
\hline 11 & Cantharellus cibarius & Polysaccharides & NK92 cells & [93] \\
\hline 12 & Agrocybe aegerita & Antitumor lectin & $\begin{array}{c}\text { HeLa, SW480, SGC-7901, } \\
\text { MGC80-3, BGC-823, HL-60, and } \\
\text { mouse sarcoma S-180 }\end{array}$ & [94] \\
\hline 13 & A. aegerita & A. aegerita galectin & $4 \mathrm{~T} 1$ cells & [95] \\
\hline 14 & Agaricus bisporus & Gal $\beta-1,3$-GalNAc-binding lectin & HT29 colon cancer cells & [96] \\
\hline 15 & Armillaria luteo-virens & dimeric lectin & $\begin{array}{l}\text { MBL2 cells, HeLa cells, and } \\
\text { L1210 cells }\end{array}$ & [97] \\
\hline 16 & Boletus speciosus & B. speciosus hemagglutinin & Hep G2 cells and L1210 & [98] \\
\hline 17 & Clitocybe nebularis & Lectin & Human leukemic T cells & [99] \\
\hline 18 & Flammulina velutipes & Hemagglutinin & Leukemia L1210 cells & [100] \\
\hline 19 & Ganoderma capense & Lectin & $\begin{array}{l}\text { L1210 and M1 cells and HepG2 } \\
\text { cells }\end{array}$ & [101] \\
\hline 20 & Grifola frondosa & $\begin{array}{l}\text { N-acetylgalactosamine-specific } \\
\text { lectin }\end{array}$ & HeLa cells & [102] \\
\hline 21 & Hericium erinaceum & H. erinaceum agglutinin & HepG2 and MCF7 & [69] \\
\hline 22 & A. bisporus & Mannogalactoglucan & HepG2 cells & [103] \\
\hline 23 & Ganoderma lucidum & G. lucidum polysaccharides & HT29 cells & [104] \\
\hline 24 & G. lucidum & G. lucidum polysaccharides & $\begin{array}{l}\text { LNCaP human prostate cancer } \\
\text { cells }\end{array}$ & [105] \\
\hline 25 & G. lucidum & G. lucidum polysaccharides & K562 and RG2 cells & [106] \\
\hline 26 & Grifola frondosa & G. frondosa polysaccharides & MCF-7 and MDA-MB-231 & [107] \\
\hline 27 & Hericium erinaceus & HEFP-2b polysaccharide & HCT-116 cancer cells & [108] \\
\hline 28 & Lentinus edodes & $\begin{array}{c}\text { Mannogalactoglucan-type } \\
\text { polysaccharides }\end{array}$ & Sarcoma 180 solid tumor & [109] \\
\hline 29 & L. edodes & Homogeneous polysaccharide & $\begin{array}{l}\text { Human cervical carcinoma HeLa } \\
\text { cells }\end{array}$ & [110] \\
\hline 30 & Cordyceps sinensis & C. sinensis polysaccharide & HCT116 cancer cell line & [111] \\
\hline 31 & Pleurotus eryngii & P. eryngii polysaccharides & HepG-2 & [112] \\
\hline 32 & Pleurotus ostreatus & P. ostreatus polysaccharide & Murine lymphoid cancer cell line & [113] \\
\hline
\end{tabular}

\subsection{Mushrooms as Immunomodulators}

The immune system is a combination of specialized cells and protein networks that protects the body against infection. The level of immunity decides how healthy a person is. The active part of mushrooms acts along with the human body's immune system and fights against diseases. The mushroom acts via modulating the innate and adaptive immune system (Figure 2). The host pattern recognition receptors and pathogen-associated molecular patterns decide the response after invasion by foreign bodies. The pattern recognition receptors activate the innate immunity after pathogen recognition, while Tolllike receptors activate the pathways coordinating with the innate immunity and trigger the immunity response [114]. 


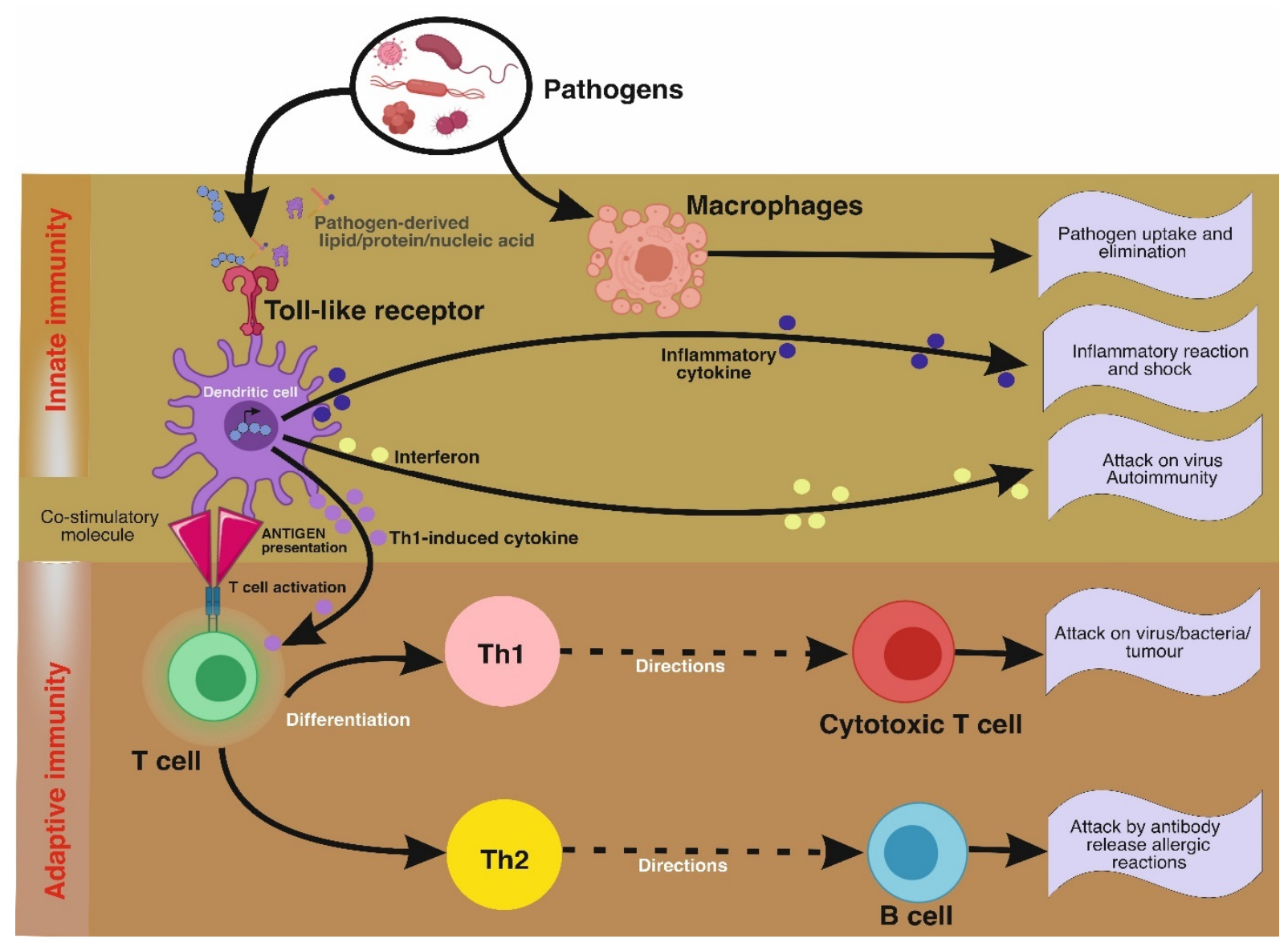

Figure 2. The schematic diagram for the mechanism of innate and adaptive immunity; activity of mushroom extracts on cyclic pathways, adapted from [115].

Velde et al. studied the immunomodulatory potential of the Agaricus subrufescens and Coprinus comatus species of mushroom using the THP-1 cells [116]. Various other researchers also evaluated the upregulation of genes using the extracts of Ganoderma lucidum, L. edodes, Agaricus bisporus, and A. subrufescens [117-120]. Velde et al. isolated the polysaccharide fraction of two mushrooms as curdlan and zymosan. They observed that the polysaccharides could induce cytokine secretion as a better response on THP1 macrophages than THP-1 monocytes, showing polysaccharides' immunomodulatory potential, while cell differentiation results showed that the zymosan and $A$. subrufescens polysaccharide showed limited potency compared to standard compounds. In another study, researchers studied the immunomodulatory effect of Pleurotus albidus, as basidiome with cold water, hot water, hot alkali and Exo, and endopolysaccharide. The basidiome extracts were able to stimulate the production of TNF- $\alpha$ and nitric oxide, but no IL- 6 was generated. Moreover, the phagocytosis activity of zymosan particles decreased [121].

Lin et al. studied the response of Maitake MD-fraction from the Grifola frondosa (active component $\beta$-glucan), showing an increase in the response of granulocytes, macrophages (CFU-GM) to bone marrow cells progenitors [122]. Moreover, the recovery pattern showed a rise for CFU-GM after administration of doxorubicin (DOX) induced hematopoietic suppression. PG101, a water-soluble extract derived from L. lepideus, activates the selective cytokines by controlling the cellular transcription factor, Nuclear factor- $\mathrm{B}$ [123]. Administration to mice increased GCF-GM. In addition, PG101 increased the number of granulocytes and myeloid progenitors. The morphological studies showed the PG101 induced the differentiation of progenitor cells to granulocytes. The levels of GM-CSF, IL-6, and IL-1 $\beta$ also showed a spike after per se administration of PG101. The fruiting bodies from the Glucidum, after treatment, showed a rise in levels of IL- $1 \beta$, TNF- $\alpha$, and 
IL-6 by many folds. Moreover, the administration resulted in the release of IFN- $\gamma$ from T lymphocytes showing their role in the antitumor activity of this extract [124].

The 6-branched 1,3- $\beta$-D-glucan (SCG), derived from the Sparassis Crispa has antitumor activity [125]. The administration of SCG enhanced the hematopoietic response in cyclosporine-induced leukopenic mice by the intraperitoneal route. The monocytes and granulocytes present in the peritoneal cavity, liver, and spleen showed faster recovery in control. Moreover, the ratio of natural killer cells and $\gamma$ delta $\mathrm{T}$ cells in the liver and spleen increased. However, the $\mathrm{CD} 4^{+}$and $\mathrm{CD}^{+}$cells decreased, and production of IL-6 and BMCs increased. Thus, this shows the possibility that IL-6 may contribute towards the enhanced hematopoietic response. Researchers studied the effect of Agaricus blazei Murrill, Antrodia cinnamomea, Ganoderma lucidum, and Hirsutella Sinensis [126]. The water and ethanol-based extracts showed remarkable effects on NK cells. The water extracts enhanced NK cell cytotoxicity against the cancer cells, while ethanol extract inhibited the cytotoxicity. The presence of water in extract stimulates the expression and production of perforin and granulysin and activates the signaling kinases such as ERK, JNK, and p38, while with ethanol, inhibition in the expression of cytolytic and cell surface receptors was reported. This finding shows that the mode of extraction of mushroom proteins may cause different pharmacological actions.

Similarly, another group of researchers found that the alkali-soluble polysaccharide and water-soluble polysaccharide-protein complex derived from the Pleurotus rhinoceros showed immunomodulatory effects in murine bone marrow-derived dendritic cells [127]. The extracts caused morphological changes in the cells and induced phenotypic and functional maturation of dendritic cells. The alkali-based polysaccharide upregulates the expression of CD86, while the water-soluble polysaccharide upregulates CD40, CD80, and 86 cells and also binds to the dectin- 1 receptor and stimulates the release of MIP- $1 \alpha$, MIP-2, and IL-2. The water-based polysaccharide binds to complement receptor 3 and toll-like receptor 2 with upregulation of IL-2, IL-6, MIP-1 $\alpha$, MIP-2, RANTES, IL-12p40p70, IL-12p70, TIMP-1, IFN- $\gamma$, KC, MCP-1, and GCSF [127]. Polyporus rhinoceros produces the immunologically active novel micro-particulate $\beta$-glucan known as PRA-1p. PRA-1p is produced via emulsification and crosslinking of PRA-1, which is chemically hyperbranched $(1 \rightarrow 3),(1 \rightarrow 6)-\beta$-d-glucan [128]. The PRA-1p pharmacologically induces the morphological changes in RAW 264.7 cells and generates nitric oxide and reactive oxygen species formation. Moreover, PRA-1p enhances the secretion of cytokines, granulocyte colony-stimulating factor, macrophages inflammatory protein, etc., while with RAW 264.7, cells' activation of nitric oxide synthase, NF- $\mathrm{kB}$, extracellular signal-regulated kinase, and protein kinase $B$ takes place. Many of the other papers citing the immunomodulatory effect of mushrooms have been tabulated in Table 4 .

Table 4. Mushrooms having an immunomodulatory effect.

\begin{tabular}{cccc}
\hline Source & Immunomodulatory Effect & References \\
\hline Auricularia auricula-judae & Induces apoptosis of cancer cell & [129] \\
\hline Agaricus blazei & Activates the NK cells, macrophages, dendritic cells, and granulocytes & [130] \\
\hline Agaricus bisporus & Obstruct multiplying of L1210 and HT-29 cells & [41] \\
\hline Agrocybe aegerita & Obstruct multiplying of 4T1, HeLa, SW480 SGC7901, MGC803, BGC823, & HL-60, and S180 cells & [95] \\
\hline Amanita phalloides & Obstruct multiplying of L1210 cells & [131] \\
\hline Boletus edulis & Arouse mice splenocytes mitogenicity and obstruct multiplying of human & \\
\hline Boletus speciosus & hepatocyte carcinoma G2 (HepG2) and HT-29 cells & [132] \\
\hline Cryptoporus volvatus & Obstruct multiplying of HepG2 and L1210 cells & [133] \\
\hline
\end{tabular}


Table 4. Cont.

\begin{tabular}{|c|c|c|}
\hline Source & Immunomodulatory Effect & References \\
\hline $\begin{array}{l}\text { Cerioporus squamosus } \\
\text { (syn. Polyporus squamosus) }\end{array}$ & Obstruct multiplying of HeLa cells & [134] \\
\hline Clitocybe nebularis & Obstruct multiplying of human leukemic T cells & [99] \\
\hline Chroogomphis rutilus & $\begin{array}{l}\text { Arouse the proliferation of murine splenocytes and improved the secretion } \\
\text { of IL-2 }\end{array}$ & [135] \\
\hline Dichomitus squalens & Prompt apoptosis and interrupt the migration of A549 cells & [136] \\
\hline Flammulina velutipes & Upsurges NO, IL-1 production, and TNF- $\alpha$ secretion & [137] \\
\hline Flammulina velutipes & Excite mice splenocytes mitogenicity and obstruct multiplying of L1210 cells & [100] \\
\hline $\begin{array}{c}\text { Floccularia luteovirens } \\
\text { (syn. Armillaria luteovirens) }\end{array}$ & $\begin{array}{l}\text { Excite mice splenocytes mitogenicity and inhibit proliferation of L1210, } \\
\text { Mouse myeloma MBL2 and HeLa cells }\end{array}$ & [97] \\
\hline Flammulina velutipes & $\begin{array}{l}\text { Excite mitogenesis in human peripheral lymphocytes, suppress systemic } \\
\text { anaphylaxis reaction, improve transcription of IL-3, IFN- } \gamma\end{array}$ & [138] \\
\hline Ganoderma lucidum & Excite TNF- $\alpha$, IL-1, IFN- $\gamma$ production, activates NF- $k B$ & [139] \\
\hline Grifola frondosa & Macrophage activation, induction of IL-1, IL-6, and TNF- $\alpha$ secretion & [140] \\
\hline $\begin{array}{l}\text { Gymnopus dryophilus } \\
\text { (syn. Collybia dryophila) }\end{array}$ & Constrains NO production in activated macrophages & [141] \\
\hline Ganoderma capense & $\begin{array}{l}\text { Arouse mice splenocytes mitogenicity and inhibit proliferation of L1210, M1, } \\
\qquad \text { HepG2 cells }\end{array}$ & [101] \\
\hline Grifola frondosa & Constrain the proliferation of HeLa & {$[102]$} \\
\hline Ganoderma sinensis & Augment production of IL-2, IL-3, IL-4, IFN- $\gamma$, TNF- $\alpha$ & [142] \\
\hline Ganoderma microsporum & Downregulation of TNF- $\alpha$ & [143] \\
\hline Ganoderma tsugae & $\begin{array}{l}\text { Persuade cytokine secretion, cellular multiplication of human peripheral } \\
\text { mononuclear cells (HPBMCs) enhancing IFN- } \gamma \text { expression }\end{array}$ & [144] \\
\hline Ganoderma lucidum & $\begin{array}{l}\text { Trigger THP-1 macrophages and induce proinflammatory cytokine } \\
\text { transcription }\end{array}$ & [145] \\
\hline Ganoderma lucidum & Augment transcription of IL-2, IL-3, IL-4, IFN- $\gamma$, TNF- $\alpha$ & [146] \\
\hline Hericium erinaceus & Persuades NO production, increases expression of TNF- $\alpha$, IL-1 $\beta$, IL-12 & [147] \\
\hline I. obliquus & $\begin{array}{l}\text { Augment expression of IL- } 1 \beta, \text { IL- } 6 \text {, TNF- } \alpha \text {, and inducible nitric oxide } \\
\text { synthase (iNOS) in macrophages }\end{array}$ & [148] \\
\hline Intrageneric shuffled library & Encourage U-251 MG cells apoptosis & [149] \\
\hline Kurokawa leucomelas & Constrain the proliferation of U937 cells & [150] \\
\hline $\begin{array}{l}\text { Lentinula edodes } \\
\text { (syn. Lentinus edodes) }\end{array}$ & $\begin{array}{l}\text { Encourages non-specific cytotoxicity in macrophage and augment cytokine } \\
\text { production }\end{array}$ & [151] \\
\hline Lentinus squarrosulus & Stimulation of macrophages, splenocytes, and thymocytes & [152] \\
\hline Lignosus rhinocerotis & Hinder the multiplication of HeLa, MCF7, and A549 cells & [153] \\
\hline Lactarius flavidulus & Obstruct the multiplying of HepG2 and L1210 cells & [154] \\
\hline $\begin{array}{l}\text { Leucocalocybe mongolica } \\
\text { (syn. Tricholoma mongolicum) }\end{array}$ & Hinder the production of S180 cells & [155] \\
\hline Macrocybe gigantea & $\begin{array}{l}\text { Upsurges phagocytic function of macrophages by activating macrophages to } \\
\text { release mediators such as NO and TNF- } \alpha \text { and inhibits S180 and HL-60 cells }\end{array}$ & [156] \\
\hline Marasmius oreades & Hinder the proliferation of SW480, HepG2, and NIH-3T3 cells & [157] \\
\hline Morchella esculenta & Macrophage activation, trigger NF- $\mathrm{kB}$ & [158] \\
\hline
\end{tabular}


Table 4. Cont.

\begin{tabular}{|c|c|c|}
\hline Source & Immunomodulatory Effect & References \\
\hline Morchella conica & Encourages NO, IL-1 $\beta$, IL-6 making & [159] \\
\hline Naematelia aurantialba & Improves mouse spleen lymphocyte multiplication & [160] \\
\hline Pleurotus sp.'Florida' & Arouses macrophages, splenocytes, and thymocytes & [161] \\
\hline Poria cocos & Promotes the immune reaction; increases the expression of cytokines & [162] \\
\hline Pleurotus ostreatus & Encourages IL- 4 and IFN- $\gamma$ production & [163] \\
\hline $\begin{array}{l}\text { Pseudosperma umbrinellum (syn } \\
\text { Inocybe umbrinella) }\end{array}$ & Obstruct multiplication of HepG2 and MCF7 cells & [164] \\
\hline Pleurotus eous & Obstruct multiplication of MCF7, K562, and HepG2 & [165] \\
\hline Pleurotus citrinopileatus & $\begin{array}{l}\text { Arouse mice splenocytes mitogenicity and obstruct multiplication of } \\
\qquad \text { S180 cells }\end{array}$ & [33] \\
\hline Pholiota adiposa & Obstruct multiplication of HepG2 and MCF7 cells & {$[64]$} \\
\hline Postia placenta & $\begin{array}{l}\text { Arouse mouse splenocyte cell proliferation and enhance interleukin-2 (IL-2) } \\
\text { release, obstruct multiplication and persuade apoptotic effects on gastric } \\
\text { tumor cells (MGC823) }\end{array}$ & [166] \\
\hline Poria cocos & Enhance production of IL-1b, IL-6, IL-18, TNF- $\alpha$, NO & [167] \\
\hline Russula delica & Obstruct multiplication of HepG2 and MCF7 cells & [34] \\
\hline Russula lepida & Obstruct multiplication of HepG2 and MCF7 cells & [168] \\
\hline Schizophyllum commune & Instigation of $\mathrm{T}$ cell increases interleukin and TNF- $\alpha$ production & [169] \\
\hline Sparassis crispa & Boosts IL- 6 and IFN- $\gamma$ production & [170] \\
\hline Sarcodon aspratus & Upsurges the discharge of TNF- $\alpha$ and NO in macrophage & [171] \\
\hline Schizophyllum commune & $\begin{array}{l}\text { Excite mice splenocytes mitogenicity and obstruct multiplication of KB, } \\
\qquad \text { HepG2, and S180 cells }\end{array}$ & [172] \\
\hline Stropharia rugosoannulata & Obstruct multiplication of HepG2 and L1210 cells & [173] \\
\hline Trametes versicolor & Upsurges the expression of cytokines; stimulates the macrophage phagocytes & [174] \\
\hline $\begin{array}{l}\text { Taiwanofungus camphoratus (syn. } \\
\text { Antrodia camphorate) }\end{array}$ & Stimulation of IFN- $\gamma$, TNF- $\alpha$ & [175] \\
\hline $\begin{array}{l}\text { Tropicoporus linteus (syn. } \\
\text { Phellinus linteus) }\end{array}$ & Instigation of murine B cells, Induces IL-12 and IFN- $\gamma$ production & [176] \\
\hline Tremella fuciformis & Encourages human monocytes to express interleukins & [177] \\
\hline $\begin{array}{l}\text { Taiwanofungus camphoratus (Syn. } \\
\text { Antrodia camphorate) }\end{array}$ & Induce expression of different cytokines (IL-1b, IL-6, IL-12, TNF- $\alpha$ ) & [178] \\
\hline Trametes versicolor & $\begin{array}{l}\text { Increase human peripheral blood lymphocytes, enhanced production of } \\
\qquad \text { TNF- } \alpha \text {, NO }\end{array}$ & [179] \\
\hline Volvariella volvacea & Enhance expression of IL-2, IL-4, IFN- $\gamma$, TNF- $\alpha$ & [180] \\
\hline Xylaria nigripes & Inhibits NO, IL- $1 \beta$, IL- 6, TNF- $\alpha$, and IFN- $\gamma$ production & [181] \\
\hline $\begin{array}{l}\text { Xerocomellus chrysenteron (syn. } \\
\text { Xerocomus chrysenteron) }\end{array}$ & Inhibit the proliferation of NIH-3T3 and HeLa cells & [182] \\
\hline Xylaria hypoxylon & Inhibit the proliferation of HepG2 cells & [183] \\
\hline
\end{tabular}

\subsection{Antioxidant and Antibacterial Action of Mushrooms}

The reactive oxygen species (ROS) plays a vital role in the pathogenesis of various acute and chronic diseases. Antioxidants try to act via lowering the reaction in the cellular environment and thus the levels of ROS. The secondary products derived from mushrooms also play an essential role in the scavenging of ROS. Researchers exploited Pleurotus ostreatus and Coprinus comatus as ethanolic extracts for their antioxidant potential [184]. The study 
showed the extraction of $\alpha$-tocopherol, rutin, and apigenin, essential in skin protection as antioxidants. The flavonoid contents extracted from Lentinus edodes, Volvariella volvacea, Pleurotuseous, Pleurotus sajor-caju, and Auricularia auricular have been shown to possess antioxidant properties [185]. The ethanolic extract from L. edodes was found to have higher phenolic and flavonoid content than the rest. In addition, the extract showed the highest radical scavenging assay compared to the standard. Other researchers reported similar results for the Lentinus edodes and Volvariella volvacea [186].

Yoon et al. reported the antioxidant effect of Lentinus lepideus and observed that the hot water extract of mushrooms showed the strongest $\beta$ carotene-linoleic acid inhibition compared to others [187]. In addition, the methanolic extract with a concentration of $8 \mathrm{mg} / \mathrm{mL}$ showed the highest reducing power. However, the acetone and methanolic extract showed more effectiveness in scavenging action. The acetone and methanolic extract of Pleurotus florida also possesses strong inhibitory activity against the $\beta$-carotene-linoleic acid [188]. The extracts caused induction of nitric oxide production and expression of inducible nitric oxide synthase in RAW 264.7 cells and showed inhibition on the dose-dependent level. $\mathrm{Xu}$ et al. extracted the antioxidants from Thelephora ganbajun using ultrasound-assisted extraction [189]. The extraction was carried out using the design of experiments and was perfected as $57.38 \%$ ethanol, $70.15 \mathrm{~mL} / \mathrm{g}$ solvents to solid ratio, $10.58 \mathrm{~min}$ extraction time, $40{ }^{\circ} \mathrm{C}$ extraction temperature, and $500 \mathrm{~W}$ ultrasound power. Compared to the traditional extraction method involving the soxhlet apparatus, the ultrasound-assisted method showed better output in a shorter time interval. Moreover, the extracts also showed anti-proliferative action against the A549, MCF-7, HepG2, and HT-29 cell lines. The antioxidant and anti-proliferative activity was accounted for due to rutin, 2-hydrocinnamic acid, and epicatechin in extracts. Polysaccharides from Oudemansiella radicata mushroom were extracted, termed as Oudemansiella radicata polysaccharides (ORP) [190]. Three extracts were ORP-1, ORP-2, and ORP-3 with an average molecular weight of $13,921 \mathrm{Da}, 14,942 \mathrm{Da}$, and 10,209 Da. The chemical composition of extracts varied as mannose, ribose, glucose, galactose, and xylose. The ORP-1 showed the highest DPPH radical scavenging activity, while the ORP-3 showed the highest hydroxyl radical scavenging activity, along with ferrous ion chelating activity. Researchers reported the exopolysaccharides extraction from Ganoderma lingzhi using a unique media for growth; the growth increased about three times compared to growth on basal media [191]. The exopolysaccharide showed higher uronic acid content, d-mannose, l-rhamnose, and d-glucose, thus possessing higher antioxidant properties such as radical scavenging, reductive capacity, and chelation transition metal catalysis. A tabulated form of papers citing the antioxidant potential of mushrooms has been reported in Table 5 .

The antibacterial activity of methanol extract from the C. versicolor fruiting body was studied by Matijašević et al. [192]. The MIC values for different bacteria varied from 0.625 to $20 \mathrm{mg} \mathrm{mL}^{-1}$. Both Gram-positive and Gram-negative bacteria were killed by C. versicolor. The extract inhibited Staphylococcus aureus and Salmonella enterica serovar Enteritidis as measured at $630 \mathrm{~nm}$ and verified by macro dilution. S. aureus cells exposed to C. versicolor MIC looked elongated and deformed, whereas S. enteritidis treated cells seemed shorter and aggregated, with torn cell walls. The treated S. Enteritidis had a larger periplasmic gap and distorted and dispersed cell envelope components. The loss of 260-nm-absorbing material showed that the extract's cytoplasmic membrane disrupting activity was more apparent in S. aureus than S. enteritidis. Similarly, Janeš et al. reported the antibacterial activity of extracts derived from mushrooms Amanita virosa. (Fr.) Bertill. (Amanitaceae) and Cortinarius praestans. Cordier (Cortinariaceae) against Pseudomonas aeruginosa, and Staphylococcus aureus, respectively, and extract of endophytic fungus Trucatella hartigii. (Tubeuf) Steyaert (Amphisphaeriaceae) against Enterococcus faecalis and S. aureus [193]. The coprophilous mushroom Coprinopsis cinerea has a genome-wide transcriptional response to Bacillus subtilis and Escherichia coli [194]. As the genes activated by co-cultivation with each bacterium mirrored each other, it is likely that the fungal effectors used by the fungus are identical. Interestingly, comparative proteomics of the $C$. cinerea secretome revealed that 
the upregulated genes encode mainly secreted peptides and proteins with antibacterial activity. The cysteine-stabilized-defensins (Cs-defensins) and GH24-type lysozymes (GH24lysozymes) were isolated, and their antibacterial activity was verified.

Table 5. Mushrooms and their antioxidant-derived compounds.

\begin{tabular}{|c|c|c|}
\hline The Scientific Name of the Mushroom & Antioxidant Compounds & References \\
\hline Agaricus arvensis & $\beta$-Carotene, ascorbic acid, lycopene, phenolic compounds & {$[195,196]$} \\
\hline Agaricus bisporus & $\begin{array}{c}\text { Pyrogallol } \\
\text { L-ergothioneine, } \\
\alpha \text { - and } \beta \text {-glucans } \\
\text { Catechin, gallic acid, } \\
\text { rutin, caffeic acid }\end{array}$ & [197-199] \\
\hline Agaricus blazei & $\begin{array}{l}\text { Benzoic acid, myricetin, quercetin, pyrogallol } \\
\alpha \text { - and } \beta \text {-Glucans }\end{array}$ & [200-202] \\
\hline Agaricus romagnesii & Phenolic compounds, $\beta$-carotene & {$[203,204]$} \\
\hline Agaricus silvaticus & Phenolic compounds, $\beta$-carotene & {$[205,206]$} \\
\hline Agaricus silvicola & $\beta$-Carotene, ascorbic acid, lycopene, phenolic compounds & {$[207,208]$} \\
\hline Agrocybe cylindracea & $\alpha$-Tocopherol, $\beta$-tocopherol & [65] \\
\hline Amanita rubescens & Phenolics compounds, flavonoids & {$[209,210]$} \\
\hline Armillaria mellea & $\begin{array}{l}\text { Antioxidant components, ascorbic acid, flavonoids, and phenolic } \\
\text { compounds }\end{array}$ & [211-213] \\
\hline Armillaria ostoyae & Phenolic compounds & [214] \\
\hline Auricularia auricula-judae & Polysaccharides, phenolic compounds & [215-217] \\
\hline Auriculariapolytricha & Phenolic compounds & {$[218,219]$} \\
\hline Boletus badius & $\begin{array}{c}\beta \text {-Carotene, } \alpha \text {-tocopherol, } \\
\text { phenolic compounds, flavonoids }\end{array}$ & {$[220,221]$} \\
\hline Boletus edulis & $\beta$-Carotene, ascorbic acid, flavonoids, tocopherols & {$[222,223]$} \\
\hline Calocybe gambosa & Phenolic compounds, flavonoids & [224] \\
\hline Cantharellus cibarius & Phenolic compounds, flavonoids & [225-227] \\
\hline Cantharellus clavatus & Phenolic compounds & [228] \\
\hline Chlorophyllum rhacodes & Phenolic compounds & {$[229,230]$} \\
\hline Clavaria vermicularis & Flavonoids, ascorbic acid & {$[231,232]$} \\
\hline Clitocybe alexandri & Tocopherols, phenolic compounds & {$[233,234]$} \\
\hline Clitocybe geotropa & Phenolic compounds & {$[235,236]$} \\
\hline Coprinopsis atramentaria & $\beta$-Glucans & {$[237,238]$} \\
\hline Coprinus comatus & $\beta$-Carotene, ascorbic acid, lycopene, phenolic compounds & [239] \\
\hline Coriolus versicolor & Gallic, p-coumaric, protocatechin, caffeic, and vanillc acids & [240-242] \\
\hline Cortinarius glaucopus & Tocopherols, phenolic compounds & [204] \\
\hline Craterellus cornucopioides & Phenolic compounds, flavonoids & [243-246] \\
\hline Fistulina hepatica & Tocopherols, phenolic compounds & {$[247,248]$} \\
\hline Flammulina velutipes & $\begin{array}{c}\text { Gallic acid, pyrogallol, homogentisic acid, } 5 \text {-sulfosalicylic acid, } \\
\text { protocatechuic acid, quercetin, caffeic acid }\end{array}$ & {$[249,250]$} \\
\hline Ganoderma applanatum & Gallic, p-coumaric, protocatechin, caffeic, and vanillc acids & {$[251,252]$} \\
\hline Ganoderma lucidum & $\begin{array}{l}\text { Quercetin, kaempferol, } \\
\text { Triterpenoids, polysaccharides }\end{array}$ & [253-255] \\
\hline
\end{tabular}


Table 5. Cont.

\begin{tabular}{|c|c|c|}
\hline The Scientific Name of the Mushroom & Antioxidant Compounds & References \\
\hline Ganoderma tsugae & Polysaccharides & {$[256,257]$} \\
\hline Gomphus clavatus & Ergosterol, phenolic compounds & {$[258,259]$} \\
\hline Grifola frondosa & $\begin{array}{l}\text { Phenolic compounds, } \\
\beta-1,6 \text { and } \beta-1,3 \text {-glucan }\end{array}$ & [260] \\
\hline Helvella crispa & Phenolic compounds & [261] \\
\hline Hericium erinaceus & Phenolic compounds & [262] \\
\hline Hydnum repandum & Tocopherols, phenolic compounds & {$[263,264]$} \\
\hline I. obliquus & p-Hydroxybenzoic acid, quercetin, kaempferol & {$[265,266]$} \\
\hline Laccaria laccata & Tocopherols, phenolic compounds & [267] \\
\hline Lactarius citriolens & Free sugars, fatty acids, tocopherols, and phenolic acids & [268] \\
\hline Lactarius deliciosus & Phenolic compounds, flavonoids & [269-271] \\
\hline Lactarius piperatus & Phenolic compounds, flavonoids & {$[236,272]$} \\
\hline Lactarius salmonicolor & Phenolic compounds & {$[273,274]$} \\
\hline Lentinula edodes & Gallic acid, protocatechuic acid, catechin, tocopherols & [275-277] \\
\hline Lepista nuda & $\beta$-Carotene, $\alpha$-tocopherol & [278-281] \\
\hline Leucopaxillus giganteus & $\beta$-carotene, ascorbic acid, lycopene, phenolic compounds & [282] \\
\hline Macrolepiota procera & Phenolic compounds & [283] \\
\hline Marasmius oreades & Flavonoids, ascorbic acid & {$[284,285]$} \\
\hline Meripilus giganteus & Gallic, p-coumaric, protocatechin, caffeic, and vanillc acids & {$[286-288]$} \\
\hline Phellinus igniarius & Hispidin & {$[289,290]$} \\
\hline Phellinus linteus & $\begin{array}{l}\beta \text {-Tocopherol, protocatechuic acid, } \\
\text { gallic acid; pyrogallol; homogentisic acid, } \\
\alpha \text { - and } \beta \text {-glucans }\end{array}$ & [291] \\
\hline Pleurotus ostreatus & $\begin{array}{l}\text { } \beta \text {-Glucans } \\
\text { gallic acid, homogentisic acid, naringin, myricetin, tocopherols, } \\
\text { glycoproteins, } \beta \text {-D-Glucan (pleuran) Lectin }\end{array}$ & [292-294] \\
\hline Pleurotus pulmonarius & Flavonoids, ascorbic acid & {$[295,296]$} \\
\hline Pycnoporus sanguineus & Phenolic compounds & {$[297,298]$} \\
\hline Ramaria botrytis & Tocopherols, phenolic compounds, ascorbic acid, $\beta$-carotene & [299-301] \\
\hline Russula vinosa & Phenolic compounds & {$[302,303]$} \\
\hline Schizophyllum commune & $\alpha$ - and $\beta$-Glucans, phenolic compounds & [304-306] \\
\hline Sparassis crispa & Protocatechuic acid, benzoic acid, $p$-hydroxybenzoic acid & [307] \\
\hline
\end{tabular}

\subsection{Hepatoprotective Potentials of Mushrooms}

Several researchers reported the protective action of mushrooms on experimentally induced liver injuries. Morel mushrooms have been reported to have beneficial action against the $\mathrm{CCL}_{4}$ and ethanol-induced hepatotoxicity [308]. Treatment with mushroom extract resulted in lowering the levels of GOT (Glutamic oxaloacetic transaminase), GPT (Glutamic pyruvic transaminase), and ALP (Alkaline phosphatase) in a dose-dependent manner. A similar kind of result was reported by Wu et al. to use Ganoderma lucidum [309]. Liu et al. extracted the polysaccharides such as water-soluble polysaccharides and alkali-soluble polysaccharides from the Oudemansiella radicata [310]. Administration of polysaccharides resulted in lower serum alanine aminotransferase and aspartate aminotransferase, and it stimulated the hepatic superoxide dismutase and glutathione peroxidase. Nisar et al. 
reported the hepatoprotective action of actives isolated from Lentinus edodesin in hypercholesterolemic rats [311].

\subsection{Anti-Inflammatory Action of Mushroom}

The anti-inflammatory action of mushrooms is based on macrophages mediating via inhibiting the signaling pathways such as prostaglandins release, ROS production, activation of transcription 1 and STAT6, and NF- $\mathrm{kB}[312,313]$. Chien et al. studied the anti-inflammatory action of the Grifola frondosa and Ophioconrdyceps spp. It was reported that the production of nitric oxide affected tumor necrosis factor- $\alpha$, while the production of nitric oxide interleukin-10 was increased [314]. Yuan et al. reported the role of bioactive protein PEP derived from Pleurotus eryngii. PEP showed anti-inflammatory activity in RAW 264.7 macrophages, inhibiting pro-inflammatory mediators' production and inhibiting inducible nitric oxide synthase expression, showing its potency for anti-inflammatory activity in the colon [315]. Liu et al. reported the action of polysaccharides derived from Hypsizygus marmoreus on LPS in lungs [316].

\section{Clinical Trails}

The clinical trials were searched using clinicaltrials.gov (accessed on 27 August 2021). The criteria for searching the trials included trials completed and results reported. The number of clinical trials was reported for the use of mushrooms in treatment, and therapeutic interventions were relatively low (Total 8 nos, 6 nos was relevant to the use of mushrooms; two clinical trials were excluded). Table 6 outlines many of the useful clinical trials which provide evidence of the usefulness of mushrooms. Many other researchers had also summed up the role of mushrooms on cancer risk, gut health, and mortality [317-322].

Table 6. Tabulated data about Clinical trials involving mushrooms.

\begin{tabular}{|c|c|c|c|}
\hline Clinical Trial No. & Intervention Model & Details of Trial and Outcome & References \\
\hline NCT01398176 & Parallel Assignment & $\begin{array}{l}\text { Consuming Lentinula edodes daily resulted in } \\
\text { improvement in immunity and cellular proliferation. }\end{array}$ & {$[323,324]$} \\
\hline NCT01099917 & Single Group Assignment & $\begin{array}{l}\text { Administration of Maitake mushroom showed } \\
\text { improvement in Hematopoiesis in Myelodysplastic } \\
\text { Patients during Phase II evaluation }\end{array}$ & {$[325,326]$} \\
\hline NCT01414010 & Parallel Assignment & $\begin{array}{l}\text { The comparative analysis of administrating Trametes } \\
\text { Versicolor, Saccharomyces Boulardii, and amoxicillin to } \\
\text { subjects. The Trametes versicolor administration showed } \\
\text { a significant reduction in bacterial percentage in the stool. }\end{array}$ & [327] \\
\hline NCT01402115 & Parallel Assignment & $\begin{array}{l}\text { Administration of polycan (a purified } \beta \text {-glucan from } \\
\text { Aureobasidium pullulans) resulted in a reduction in bone } \\
\text { loss and biomarkers present due to bone metabolism }\end{array}$ & [328] \\
\hline NCT00465595 & Crossover Assignment & $\begin{array}{l}\text { The use of Psilocybin } \\
\text { This resulted in a decrease in mood anxiety and } \\
\text { depression and increased well-being/life satisfaction }\end{array}$ & {$[329,330]$} \\
\hline NCT04186780 & Parallel Assignment & $\begin{array}{c}\text { Consumption of } L . \text { edodes Bars } \\
\text { This resulted in a decrease in oxidative stress and } \\
\text { Dyslipidemia } \\
\text { in border line patients }\end{array}$ & [331] \\
\hline
\end{tabular}

\section{Recommendations and Future Perspectives}

Various mushrooms have been found and tested to possess a bioactive role in treating multiple disorders besides their beneficial health effects. They have been included in dietary supplements by multiple organizations. The role of the bioactive is determined by the type of extraction procedure carried out. It has been found that the choice of solvent used for extraction determines the quantity and quality of the bioactive derived. 
The primary and secondary metabolites showed outstanding properties for treating and preventing many life-threatening diseases. Bioactive compounds showing therapeutic action include polysaccharides, proteins, peptides, enzymes, and other compounds. They have been based on inhibiting viral proteins, enhance immunity, etc. Many formulations of mushrooms such as paste and powder present low amounts of fats and can be used as antioxidants to prevent oxidative stress and aging. However, due to many mushroom varieties existing, many of them have been remained untouched, and their pharmacological action has not been determined. Thus, there is a need to explore the other side of the coin complemented with advanced interventions and additional clinical trials

Supplementary Materials: The following are available online at https://www.mdpi.com/article/10 .3390/jof7090728/s1, Table S1: Name and a molecular formula of constituent compounds of APH (hexane crude extract of Auricularia polytricha).

Author Contributions: Conceptualization, H.C. and Y.K.M.; original draft preparation, H.C., A.K.M., Y.K.M., and A.A.B.; writing-review and editing, A.K.M., T.K.M., Y.K.M., and K.-H.B.; visualization, H.C.; supervision, K.-H.B. All authors have read and agreed to the published version of the manuscript.

Funding: This research was funded by the National Research Foundation of Korea [NRF2019R1F1A1052625], Republic of Korea.

Institutional Review Board Statement: Not applicable.

Informed Consent Statement: Not applicable.

Data Availability Statement: Not applicable.

Acknowledgments: This work was supported by the National Research Foundation of Korea, Republic of Korea [Grant number-NRF2019R1F1A1052625].

Conflicts of Interest: The authors declare no conflict of interest.

\section{References}

1. Alves, M.; Ferreira, I.F.R.; Dias, J.; Teixeira, V.; Martins, A.; Pintado, M. A review on antimicrobial activity of mushroom (basidiomycetes) extracts and isolated compounds. Planta Med. 2012, 78, 1707-1718. [CrossRef]

2. Reis, F.S.; Barros, L.; Martins, A.; Ferreira, I.C.F.R. Chemical composition and nutritional value of the most widely appreciated cultivated mushrooms: An inter-species comparative study. Food Chem. Toxicol. 2012, 50, 191-197. [CrossRef] [PubMed]

3. Blumfield, M.; Abbott, K.; Duve, E.; Cassettari, T.; Marshall, S.; Fayet-Moore, F. Examining the health effects and bioactive components in Agaricus bisporus mushrooms: A scoping review. J. Nutr. Biochem. 2020, 84, 108453. [CrossRef] [PubMed]

4. Ndung'u, S.W.; Otieno, C.A.; Onyango, C.; Musieba, F. Nutritional composition, physical qualities and sensory evaluation of wheat bread supplemented with Oyster Mushroom. Am. J. Food Technol. 2015, 10, 279-288. [CrossRef]

5. Bernas, E. Monosodium glutamate equivalents and B-group vitamins in frozen mushrooms. Int. J. Food Prop. 2017, 20, 1613-1626. [CrossRef]

6. Cardwell, G.; Bornman, J.F.; James, A.P.; Black, L.J. A review of mushrooms as a potential source of dietary vitamin D. Nutrients 2018, 10, 1948. [CrossRef]

7. Keflie, T.S.; Nölle, N.; Lambert, C.; Nohr, D.; Biesalski, H.K. Impact of the natural resource of UVB on the content of vitamin D2 in oyster mushroom (Pleurotus ostreatus) under subtropical settings. Saudi J. Biol. Sci. 2019, 26, 1724-1730. [CrossRef]

8. Jiang, Q.; Zhang, M.; Mujumdar, A.S. UV induced conversion during drying of ergosterol to vitamin D in various mushrooms: Effect of different drying conditions. Trends Food Sci. Technol. 2020, 105, 200-210. [CrossRef]

9. Fischer, M.W.F.; Money, N.P. Why mushrooms form gills: Efficiency of the lamellate morphology. Fungal Biol. 2010, 114, 57-63. [CrossRef]

10. Mapoung, S.; Umsumarng, S.; Semmarath, W.; Arjsri, P.; Thippraphan, P.; Yodkeeree, S.; Pornngarm, L. Skin wound-healing potential of polysaccharides from medicinal mushroom Auricularia auricula-judae (Bull.). J. Fungi 2021, 7, 247. [CrossRef]

11. Dunnill, C.; Patton, T.; Brennan, J.; Barrett, J.; Dryden, M.; Cooke, J.; Leaper, D.; Georgopoulos, N.T. Reactive oxygen species (ROS) and wound healing: The functional role of ROS and emerging ROS-modulating technologies for augmentation of the healing process. Int. Wound J. 2017, 14, 89-96. [CrossRef]

12. Veeraperumal, S.; Qiu, H.M.; Zeng, S.S.; Yao, W.Z.; Wang, B.P.; Liu, Y.; Cheong, K.L. Polysaccharides from Gracilaria lemaneiformis promote the HaCaT keratinocytes wound healing by polarised and directional cell migration. Carbohydr. Polym. 2020, $241,116310$. [CrossRef] [PubMed] 
13. Chopra, H.; Kumar, S.; Singh, I. Strategies and Therapies for Wound Healing: A Review. Curr. Drug Targets 2021, 22. (online ahead of print). [CrossRef]

14. De Jesus, L.I.; Smiderle, F.R.; Ruthes, A.C.; Vilaplana, F.; Dal'Lin, F.T.; Maria-Ferreira, D.; Werner, M.F.; Van Griensven, L.J.L.D.; Iacomini, M. Chemical characterization and wound healing property of a $\beta$-D-glucan from edible mushroom Piptoporus betulinus. Int. J. Biol. Macromol. 2018, 117, 1361-1366. [CrossRef]

15. Rao, K.M.; Suneetha, M.; Park, G.T.; Babu, A.G.; Han, S.S. Hemostatic, biocompatible, and antibacterial non-animal fungal mushroom-based carboxymethyl chitosan-ZnO nanocomposite for wound-healing applications. Int. J. Biol. Macromol. 2020, 155, 71-80. [CrossRef] [PubMed]

16. Kwon, A.H.; Qiu, Z.; Hashimoto, M.; Yamamoto, K.; Kimura, T. Effects of medicinal mushroom (Sparassis crispa) on wound healing in streptozotocin-induced diabetic rats. Am. J. Surg. 2009, 197, 503-509. [CrossRef] [PubMed]

17. Kaplan, Ö.; Gökşen Tosun, N.; Özgür, A.; Erden Tayhan, S.; Bilgin, S.; Türkekul, İ.; Gökce, İ. Microwave-assisted green synthesis of silver nanoparticles using crude extracts of Boletus edulis and Coriolus versicolor: Characterization, anticancer, antimicrobial and wound healing activities. J. Drug Deliv. Sci. Technol. 2021, 64, 102641. [CrossRef]

18. Batterbury, M.; Tebbs, C.A.; Rhodes, J.M.; Grierson, I. Agaricus bisporus (edible mushroom lectin) inhibits ocular fibroblast proliferation and collagen lattice contraction. Exp. Eye Res. 2002, 74, 361-370. [CrossRef] [PubMed]

19. Sui, Z.F.; Yang, R.; Liu, B.; Gu, T.M.; Zhao, Z.L.; Shi, D.F.; Chang, D.Q. Chemical analysis of Agaricus blazei polysaccharides and effect of the polysaccharides on IL-1 $\beta$ mRNA expression in skin of burn wound-treated rats. Int. J. Biol. Macromol. 2010, 47, 155-157. [CrossRef]

20. Da Silva, G.R.; Franklin, V.; Cambuí, J.M.; de Almeida, D.T.; Wadt, N.S.Y.; Cardoso, V.O.; Bach, E.E. Effect of Agaricus sylvaticus (Schaeffer) extract in rats skin wound healing. Biomed. J. Sci. Tech. Res. 2018, 10, 7598-7600.

21. Khamrai, M.; Banerjee, S.L.; Kundu, P.P. A sustainable production method of mycelium biomass using an isolated fungal strain Phanerochaete chrysosporium (accession no: KY593186): Its exploitation in wound healing patch formation. Biocatal. Agric. Biotechnol. 2018, 16, 548-557. [CrossRef]

22. Gao, Y.; Tang, W.; Gao, H.; Chan, E.; Lan, J.; Zhou, S. Ganoderma lucidum polysaccharide fractions accelerate healing of acetic acid-induced ulcers in rats. J. Med. Food 2004, 7, 417-421. [CrossRef]

23. Lin, H.J.; Chang, Y.S.; Lin, L.H.; Haung, C.F.; Wu, C.Y.; Ou, K.L. An immunomodulatory protein (Ling Zhi-8) from a Ganoderma lucidum induced acceleration of wound healing in rat liver tissues after monopolar electrosurgery. Evid. Based Complement. Altern. Med. 2014, 2014, 916531. [CrossRef]

24. Yamamoto, K.; Kimura, T. Orally and topically administered Sparassis crispa (hanabiratake) improved healing of skin wounds in mice with streptozotocin-induced diabetes. Biosci. Biotechnol. Biochem. 2013, 77, 1303-1305. [CrossRef] [PubMed]

25. Abdulla, M.A.; Fard, A.A.; Sabaratnam, V.; Wong, K.H.; Kuppusamy, U.R.; Abdullah, N.; Ismail, S. Potential activity of aqueous extract of culinary- medicinal Lion's Mane mushroom, Hericium erinaceus (Bull.: Fr.) Pers. (Aphyllophoromycetideae) in accelerating wound healing in rats. Int. J. Med. Mushrooms 2011, 13, 33-39. [CrossRef] [PubMed]

26. Bae, J.S.; Jang, K.H.; Jin, H.K. Polysaccharides isolated from Phellinus gilvus enhances dermal wound healing in streptozotocininduced diabetic rats. J. Vet. Sci. 2005, 6, 161-164. [CrossRef] [PubMed]

27. Kim, J.Y.; Lee, Y.M.; Park, J.P.; Lim, K.T.; Lee, S.J. Phytoglycoprotein isolated from Dioscorea batatas Decne promotes intestinal epithelial wound healing. Chin. J. Nat. Med. 2020, 18, 738-748. [CrossRef]

28. Chen, F.; Zhang, Q.; Wu, P.; Zhao, Y.; Suo, X.; Xiao, A.; Ke, M.; He, X.; Tong, Z.; Chen, Y. Green fabrication of seedbed-like Flammulina velutipes polysaccharides-derived scaffolds accelerating full-thickness skin wound healing accompanied by hair follicle regeneration. Int. J. Biol. Macromol. 2021, 167, 117-129. [CrossRef] [PubMed]

29. Safaee-Ardakani, M.R.; Hatamian-Zarmi, A.; Sadat, S.M.; Mokhtari-Hosseini, Z.B.; Ebrahimi-Hosseinzadeh, B.; Rashidiani, J.; Kooshki, H. Electrospun Schizophyllan/polyvinyl alcohol blend nanofibrous scaffold as potential wound healing. Int. J. Biol. Macromol. 2019, 127, 27-38. [CrossRef]

30. Nor Azlan, A.Y.H.; Katas, H.; Habideen, N.H.; Mh Busra, M.F. Dual-action of thermoresponsive gels containing DsiRNA-loaded gold nanoparticles for diabetic wound therapy: Characterization, in vitro safety and healing efficacy. Saudi Pharm. J. 2020, 28, 1420-1430. [CrossRef]

31. Figueira, M.S.; Sá, L.A.; Vasconcelos, A.S.; Moreira, D.R.; Laurindo, P.S.O.C.; Ribeiro, D.R.G.; Santos, R.S.; Guzzo, P.; Dolabela, M.F.; Percario, S. Nutritional supplementation with the mushroom Agaricus sylvaticus reduces oxidative stress in children with HIV. Can. J. Infect. Dis. Med. Microbiol. 2014, 25, 257-264. [CrossRef] [PubMed]

32. Djohan, Y.F.; Camara, C.; Mondé, A.A.; Koffi, G.; Niamké, G.; Déré, L.; Tiahou, G.; Djessou, P.; Sess, D. Interest of antioxidants in the care of the patients infected by the HIV: The experience of long term administration of Alternanthera pungens herb tea. Ann. Biol. Clin. 2009, 67, 563-568.

33. Li, Y.R.; Liu, Q.H.; Wang, H.X.; Ng, T.B. A novel lectin with potent antitumor, mitogenic and HIV-1 reverse transcriptase inhibitory activities from the edible mushroom Pleurotus citrinopileatus. Biochim. Biophys. Acta Gen. Subj. 2008, 1780, 51-57. [CrossRef]

34. Zhao, S.; Zhao, Y.; Li, S.; Zhao, J.; Zhang, G.; Wang, H.; Ng, T.B. A novel lectin with highly potent antiproliferative and HIV-1 reverse transcriptase inhibitory activities from the edible wild mushroom Russula delica. Glycoconj. J. 2010, 27, 259-265. [CrossRef]

35. Singh, R.S.; Bhari, R.; Kaur, H.P. Mushroom lectins: Current status and future perspectives. Crit. Rev. Biotechnol. 2010, 30, 99-126. [CrossRef] [PubMed] 
36. Li, N.; Li, L.; Fang, J.C.; Wong, J.H.; Ng, T.B.; Jiang, Y.; Wang, C.R.; Zhang, N.Y.; Wen, T.Y.; Qu, L.Y.; et al. Isolation and identification of a novel polysaccharide-peptide complex with antioxidant, anti-proliferative and hypoglycaemic activities from the abalone mushroom. Biosci. Rep. 2012, 32, 221-228. [CrossRef]

37. Collins, R.A.; Ng, T.B. Polysaccharopeptide from Coriolus versicolor has potential for use against human immunodeficiency virus type 1 infection. Life Sci. 1997, 60, 383-387. [CrossRef]

38. Adotey, G.; Quarcoo, A.; Holliday, J.C.; Fofie, S.; Saaka, B. Effect of immunomodulating and antiviral agent of medicinal mushrooms (Immune Assist 24/7 $/ 7^{\mathrm{TM}}$ ) on CD4+ T-Lymphocyte Counts of HIV-infected patients. Int. J. Med. Mushrooms 2011, 13, 109-113. [CrossRef]

39. Flórez-Sampedro, L.; Zapata, W.; Orozco, L.P.; Mejía, A.I.; Arboleda, C.; Rugeles, M.T. In vitro anti-HIV-1 activity of the enzymatic extract enriched with laccase produced by the fungi Ganoderma sp. and Lentinus sp. Vitae 2016, 23, 109-118. [CrossRef]

40. Zhao, S.; Rong, C.B.; Kong, C.; Liu, Y.; Xu, F.; Miao, Q.J.; Wang, S.X.; Wang, H.X.; Zhang, G.Q. A novel laccase with potent antiproliferative and HIV-1 reverse transcriptase inhibitory activities from mycelia of mushroom Coprinus comatus. BioMed Res. Int. 2014, 2014, 417461. [CrossRef]

41. Zhang, G.Q.; Chen, Q.J.; Hua, J.; Liu, Z.L.; Sun, Y.; Xu, X.; Han, P.; Wang, H.X. An inulin-specific lectin with anti-HIV-1 reverse transcriptase, antiproliferative, and mitogenic activities from the edible mushroom Agaricus bitorquis. BioMed Res. Int. 2019, 2019, 1341370. [CrossRef] [PubMed]

42. Sillapachaiyaporn, C.; Nilkhet, S.; Ung, A.T.; Chuchawankul, S. Anti-HIV-1 protease activity of the crude extracts and isolated compounds from Auricularia polytricha. BMC Complement. Altern. Med. 2019, 19, 351. [CrossRef] [PubMed]

43. El-Mekkawy, S.; Meselhy, M.R.; Nakamura, N.; Tezuka, Y.; Hattori, M.; Kakiuchi, N.; Shimotohno, K.; Kawahata, T.; Otake, T. Anti-HIV-1 and anti-HIV-1-protease substances from Ganoderma lucidum. Phytochemistry 1998, 49, 1651-1657. [CrossRef]

44. El Dine, R.S.; El Halawany, A.M.; Ma, C.-M.; Hattori, M. Anti-HIV-1 protease activity of lanostane triterpenes from the vietnamese mushroom Ganoderma colossum. J. Nat. Prod. 2008, 71, 1022-1026. [CrossRef]

45. Lv, H.; Kong, Y.; Yao, Q.; Zhang, B.; Leng, F.W.; Bian, H.J.; Balzarini, J.; Van Damme, E.; Bao, J.K. Nebrodeolysin, a novel hemolytic protein from mushroom Pleurotus nebrodensis with apoptosis-inducing and anti-HIV-1 effects. Phytomedicine 2009, 16, 198-205. [CrossRef]

46. Wang, C.R.; Zhou, R.; Ng, T.B.; Wong, J.H.; Qiao, W.T.; Liu, F. First report on isolation of methyl gallate with antioxidant, anti-HIV-1 and HIV-1 enzyme inhibitory activities from a mushroom (Pholiota adiposa). Environ. Toxicol. Pharmacol. 2014, 37, 626-637. [CrossRef]

47. Wang, J.; Wang, H.X.; Ng, T.B. A peptide with HIV-1 reverse transcriptase inhibitory activity from the medicinal mushroom Russula paludosa. Peptides 2007, 28, 560-565. [CrossRef] [PubMed]

48. Sillapachaiyaporn, C.; Chuchawankul, S. HIV-1 protease and reverse transcriptase inhibition by tiger milk mushroom (Lignosus rhinocerus) sclerotium extracts: In vitro and in silico studies. J. Tradit. Complement. Med. 2020, 10, 396-404. [CrossRef] [PubMed]

49. El Dine, R.S.; El Halawany, A.M.; Ma, C.M.; Hattori, M. Inhibition of the dimerization and active site of HIV-1 protease by secondary metabolites from the Vietnamese mushroom Ganoderma colossum. J. Nat. Prod. 2009, 72, 2019-2023. [CrossRef] [PubMed]

50. Wang, S.X.; Liu, Y.; Zhang, G.Q.; Zhao, S.; Xu, F.; Geng, X.L.; Wang, H.X. Cordysobin, a novel alkaline serine protease with HIV-1 reverse transcriptase inhibitory activity from the medicinal mushroom Cordyceps sobolifera. J. Biosci. Bioeng. 2012, 113, 42-47. [CrossRef]

51. Seniuk, O.F.; Gorovoj, L.F.; Beketova, G.V.; Savichuk, H.O.; Rytik, P.G.; Kucherov, I.I.; Prilutskay, A.B.; Prilutsky, A.I. Anti-infective properties of the melanin-glucan complex obtained from medicinal tinder bracket mushroom, Fomes fomentarius (L.: Fr.) Fr. (Aphyllophoromycetideae). Int. J. Med. Mushrooms 2011, 13, 7-18. [CrossRef]

52. Bruggemann, R.; Orlandi, J.M.; Benati, F.J.; Faccin, L.C.; Mantovani, M.S.; Nozawa, C.; Linhares, R.E.C. Antiviral activity of Agaricus blazei Murrill ss. Heinem extract against human and bovine herpesviruses in cell culture. Braz. J. Microbiol. 2006, 37, 561-565. [CrossRef]

53. Ullrich, R.; Le, M.H.; Nguyen, L.D.; Hofrichter, M. Laccase from the medicinal mushroom Agaricus blazei: Production, purification and characterization. Appl. Microbiol. Biotechnol. 2005, 67, 357-363. [CrossRef] [PubMed]

54. Kawagishi, H.; Nomura, A.; Yumen, T.; Mizuno, T.; Hagiwara, T.; Nakamura, T. Isolation and properties of a lectin from the fruiting bodies of Agaricus blazei. Carbohydr. Res. 2013, 183, 150-154. [CrossRef]

55. Pavlova, N.I.; Savinova, O.V.; Nikolaeva, S.N.; Boreko, E.I.; Flekhter, O.B. Antiviral activity of betulin, betulinic and betulonic acids against some enveloped and non-enveloped viruses. Fitoterapia 2003, 74, 489-492. [CrossRef]

56. Ma, L.; Chen, H.; Zhang, Y.; Zhang, N.; Fu, L. Chemical modification and antioxidant activities of polysaccharide from mushroom Inonotus obliquus. Carbohydr. Polym. 2012, 89, 371-378. [CrossRef]

57. Duru, K.C.; Kovaleva, E.G.; Danilova, I.G.; van der Bijl, P. The pharmacological potential and possible molecular mechanisms of action of Inonotus obliquus from preclinical studies. Phyther. Res. 2019, 33, 1966-1980. [CrossRef]

58. Lee, I.K.; Yun, B.S. Styrylpyrone-class compounds from medicinal fungi Phellinus and Inonotus spp., and their medicinal importance. J. Antibiot. 2011, 64, 349-359. [CrossRef]

59. Lindequist, U.; Niedermeyer, T.H.J.; Jülich, W.D. The pharmacological potential of mushrooms. Evid.-Based Complement. Altern. Med. 2005, 2, 285-299. [CrossRef] 
60. Zapora, E.; Wolkowycki, M.; Bakier, S.; Zjawiony, J.K. Phellinus igniarius: A pharmacologically active polypore mushroom. Nat. Prod. Commun. 2016, 11, 1043-1046. [CrossRef]

61. Wang, $\mathrm{H} . ; \mathrm{Ng}$, T.B. Isolation and characterization of velutin, a novel low-molecular-weight ribosome-inactivating protein from winter mushroom (Flammulina velutipes) fruiting bodies. Life Sci. 2001, 68, 2151-2158. [CrossRef]

62. Wong, J.H.; Wang, H.X.; Ng, T.B. Marmorin, a new ribosome inactivating protein with antiproliferative and HIV-1 reverse transcriptase inhibitory activities from the mushroom Hypsizigus marmoreus. Appl. Microbiol. Biotechnol. 2008, 81, 669-674. [CrossRef] [PubMed]

63. Wang, H.X.; Ng, T.B. Isolation of a novel ubiquitin-like protein from Pleurotus ostreatus mushroom with anti-human immunodeficiency virus, translation-inhibitory, and ribonuclease activities. Biochem. Biophys. Res. Commun. 2000, 276, 587-593. [CrossRef]

64. Zhang, G.Q.; Sun, J.; Wang, H.X.; Ng, T.B. A novel lectin with antiproliferative activity from the medicinal mushroom Pholiota adiposa. Acta Biochim. Pol. 2009, 56, 415-421. [CrossRef] [PubMed]

65. Ngai, P.H.K.; Zhao, Z.; Ng, T.B. Agrocybin, an antifungal peptide from the edible mushroom Agrocybe cylindracea. Peptides 2005, 26, 191-196. [CrossRef]

66. Ho Wong, J.; Bun Ng, T.; Jiang, Y.; Liu, F.; Cho Wing Sze, S.; Yanbo Zhang, K. Purification and characterization of a laccase with inhibitory activity toward HIV-1 reverse transcriptase and tumor cells from an edible mushroom (Pleurotus cornucopiae). Protein Pept. Lett. 2010, 17, 1040-1047. [CrossRef] [PubMed]

67. Zhao, Y.C.; Zhang, G.Q.; Ng, T.B.; Wang, H.X. A novel ribonuclease with potent HIV-1 reverse transcriptase inhibitory activity from cultured mushroom Schizophyllum commune. J. Microbiol. 2011, 49, 803-808. [CrossRef]

68. Ngai, P.H.K.; Ng, T.B. Lentin, a novel and potent antifungal protein from shitake mushroom with inhibitory effects on activity of human immunodeficiency virus-1 reverse transcriptase and proliferation of leukemia cells. Life Sci. 2003, 73, 3363-3374 [CrossRef]

69. Li, Y.; Zhang, G.; Ng, T.B.; Wang, H. A novel lectin with antiproliferative and HIV-1 reverse transcriptase inhibitory activities from dried fruiting bodies of the monkey head mushroom hericium erinaceum. J. Biomed. Biotechnol. 2010, 2010, 716515. [CrossRef]

70. Wang, C.R.; Ng, T.B.; Li, L.; Fang, J.C.; Jiang, Y.; Wen, T.Y.; Qiao, W.T.; Li, N.; Liu, F. Isolation of a polysaccharide with antiproliferative, hypoglycemic, antioxidant and HIV-1 reverse transcriptase inhibitory activities from the fruiting bodies of the abalone mushroom Pleurotus abalonus. J. Pharm. Pharmacol. 2011, 63, 825-832. [CrossRef]

71. Blagodatski, A.; Yatsunskaya, M.; Mikhailova, V.; Tiasto, V.; Kagansky, A.; Katanaev, V.L. Medicinal mushrooms as an attractive new source of natural compounds for future cancer therapy. Oncotarget 2018, 9, 29259. [CrossRef]

72. Ma, L.; Chen, H.; Dong, P.; Lu, X. Anti-inflammatory and anticancer activities of extracts and compounds from the mushroom Inonotus obliquus. Food Chem. 2013, 139, 503-508. [CrossRef]

73. Arata, S.; Watanabe, J.; Maeda, M.; Yamamoto, M.; Matsuhashi, H.; Mochizuki, M.; Kagami, N.; Honda, K.; Inagaki, M. Continuous intake of the Chaga mushroom (Inonotus obliquus) aqueous extract suppresses cancer progression and maintains body temperature in mice. Heliyon 2016, 2, e00111. [CrossRef] [PubMed]

74. Nakata, T.; Yamada, T.; Taji, S.; Ohishi, H.; Wada, S.I.; Tokuda, H.; Sakuma, K.; Tanaka, R. Structure determination of inonotsuoxides A and B and in vivo anti-tumor promoting activity of inotodiol from the sclerotia of Inonotus obliquus. Bioorg. Med. Chem. 2007, 15, 257-264. [CrossRef] [PubMed]

75. Park, B.T.; Na, K.H.; Jung, E.C.; Park, J.W.; Kim, H.H. Antifungal and anticancer activities of a protein from the mushroom Cordyceps militaris. Korean J. Physiol. Pharmacol. 2009, 13, 49-54. [CrossRef]

76. Kosanić, M.; Ranković, B.; Rančić, A.; Stanojković, T. Evaluation of metal concentration and antioxidant, antimicrobial, and anticancer potentials of two edible mushrooms Lactarius deliciosus and Macrolepiota procera. J. Food Drug Anal. 2016, 24, 477-484. [CrossRef]

77. Kim, D.H.; Han, K.H.; Song, K.Y.; Lee, K.H.; Jo, S.Y.; Lee, S.W.; Yoon, T.J. Activation of innate immunity by Lepiota procera enhances antitumor activity. Korean J. Pharmacogn. 2010, 41, 115-121.

78. Boobalan, T.; Sethupathi, M.; Sengottuvelan, N.; Kumar, P.; Balaji, P.; Gulyás, B.; Padmanabhan, P.; Selvan, S.T.; Arun, A. Mushroom-derived carbon dots for toxic metal Ion detection and as antibacterial and anticancer agents. ACS Appl. Nano Mater. 2020, 3, 5910-5919. [CrossRef]

79. Zeng, D.; Zhao, J.; Luk, K.H.; Cheung, S.T.; Wong, K.H.; Chen, T. Potentiation of in vivo anticancer efficacy of Selenium nanoparticles by mushroom polysaccharides surface decoration. J. Agric. Food Chem. 2019, 67, 2865-2876. [CrossRef] [PubMed]

80. Zeng, D.; Zhu, S. Purification, characterization, antioxidant and anticancer activities of novel polysaccharides extracted from Bachu mushroom. Int. J. Biol. Macromol. 2018, 107, 1086-1092. [CrossRef] [PubMed]

81. Elkhateeb, W.A.; Zaghlol, G.M.; El-Garawani, I.M.; Ahmed, E.F.; Rateb, M.E.; Abdel Moneim, A.E. Ganoderma applanatum secondary metabolites induced apoptosis through different pathways: In vivo and in vitro anticancer studies. Biomed. Pharmacother. 2018, 101, 264-277. [CrossRef] [PubMed]

82. Shomali, N.; Onar, O.; Cihan, A.C.; Akata, I.; Yildirim, O. Antioxidant, anticancer, antimicrobial, and antibiofilm properties of the culinary-medicinal fairy ring mushroom, Marasmius oreades (Agaricomycetes). Int. J. Med. Mushrooms 2019, 21, 571-582. [CrossRef] [PubMed]

83. Gu, Y.H.; Leonard, J. In vitro effects on proliferation, apoptosis and colony inhibition in ER-dependent and ER-independent human breast cancer cells by selected mushroom species. Oncol. Rep. 2006, 15, 417-423. [CrossRef] [PubMed] 
84. Wang, Y.; Bao, L.; Liu, D.; Yang, X.; Li, S.; Gao, H.; Yao, X.; Wen, H.; Liu, H. Two new sesquiterpenes and six norsesquiterpenes from the solid culture of the edible mushroom Flammulina velutipes. Tetrahedron 2012, 68, 3012-3018. [CrossRef]

85. Wang, Y.; Bao, L.; Yang, X.; Li, L.; Li, S.; Gao, H.; Yao, X.S.; Wen, H.; Liu, H.W. Bioactive sesquiterpenoids from the solid culture of the edible mushroom Flammulina velutipes growing on cooked rice. Food Chem. 2012, 132, 1346-1353. [CrossRef] [PubMed]

86. Leung, M.Y.K.; Fung, K.P.; Choy, Y.M. The isolation and characterization of an immunomodulatory and anti-tumor polysaccharide preparation from Flammulina velutipes. Immunopharmacology 1997, 35, 255-263. [CrossRef]

87. Jiang, S.M.; Xiao, Z.M.; Xu, Z.H. Inhibitory activity of polysaccharide extracts from three kinds of edible fungi on proliferation of human hepatoma SMMC-7721 cell and mouse implanted S180 tumor. World J. Gastroenterol. 1999, 5, 404-407. [CrossRef]

88. Zhao, C.; Zhao, K.; Liu, X.; Huang, Y.F.; Liu, B. In vitro antioxidant and antitumor activities of polysaccharides extracted from the mycelia of liquid-cultured Flammulina velutipes. Food Sci. Technol. Res. 2013, 19, 661-667. [CrossRef]

89. Yi, C.; Zhong, H.; Tong, S.; Cao, X.; Firempong, C.K.; Liu, H.; Fu, M.; Yang, Y.; Feng, Y.; Zhang, H.; et al. Enhanced oral bioavailability of a sterol-loaded microemulsion formulation of Flammulina velutipes, a potential antitumor drug. Int. J. Nanomed. 2012, 7, 5067-5078.

90. Ikekawa, T.; Miyano, T.; Okura, A.; Maruyama, H.; Kawamura, K.; Sawasaki, Y.; Shiratori, K.; Naito, K. Proflamin, a new antitumor agent: Preparation, physicochemical properties and antitumor Activity. Jpn. J. Cancer Res. GANN 1985, 76, 142-148. [PubMed]

91. Lau, M.-F.; Chua, K.-H.; Sabaratnam, V.; Kuppusamy, U.R. In vitro and in silico anticancer evaluation of a medicinal mushroom, Ganoderma neo-japonicum Imazeki, against human colonic carcinoma cells. Biotechnol. Appl. Biochem. 2021, 68, 902-917. [CrossRef] [PubMed]

92. Dasgupta, A.; Dey, D.; Ghosh, D.; Lai, T.K.; Bhuvanesh, N.; Dolui, S.; Velayutham, R.; Acharya, K. Astrakurkurone, a sesquiterpenoid from wild edible mushroom, targets liver cancer cells by modulating Bcl-2 family proteins. IUBMB Life 2019, 71, 992-1002. [CrossRef]

93. Lemieszek, M.K.; Nunes, F.M.; Rzeski, W. Branched mannans from the mushroom: Cantharellus cibarius enhance the anticancer activity of natural killer cells against human cancers of lung and colon. Food Funct. 2019, 10, 5816-5826. [CrossRef] [PubMed]

94. Zhao, C.; Sun, H.; Tong, X.; Qi, Y. An antitumour lectin from the edible mushroom Agrocybe aegerita. Biochem. J. 2003, 374, 321-327. [CrossRef]

95. Yang, Q.; Yin, Y.; Pan, Y.; Ye, X.; Xu, B.; Yu, W.; Zeng, H.; Sun, H. Anti-metastatic activity of Agrocybe aegerita galectin (AAL) in a mouse model of breast cancer lung metastasis. J. Funct. Foods 2018, 41, 163-170. [CrossRef]

96. Yu, L.; Fernig, D.G.; Smith, J.A.; Milton, J.D.; Rhodes, J.M. Reversible inhibition of proliferation of epithelial cell lines by Agaricus bisporus (Edible Mushroom) Lectin. Cancer Res. 1993, 53, 4627-4632.

97. Feng, K.; Liu, Q.H.; Ng, T.B.; Liu, H.Z.; Li, J.Q.; Chen, G.; Sheng, H.Y.; Xie, Z.L.; Wang, H.X. Isolation and characterization of a novel lectin from the mushroom Armillaria luteo-virens. Biochem. Biophys. Res. Commun. 2006, 345, 1573-1578. [CrossRef]

98. Sun, J.; Ng, T.B.; Wang, H.; Zhang, G. A novel hemagglutinin with antiproliferative activity against tumor cells from the hallucinogenic mushroom boletus speciosus. BioMed Res. Int. 2014, 2014, 340467. [CrossRef]

99. Pohleven, J.; Obermajer, N.; Sabotič, J.; Anžlovar, S.; Sepčić, K.; Kos, J.; Kralj, B.; Štrukelj, B.; Brzin, J. Purification, characterization and cloning of a ricin B-like lectin from mushroom Clitocybe nebularis with antiproliferative activity against human leukemic $\mathrm{T}$ cells. Biochim. Biophys. Acta Gen. Subj. 2009, 1790, 173-181. [CrossRef]

100. Ng, T.B.; Ngai, P.H.K.; Xia, L. An agglutinin with mitogenic and antiproliferative activities from the mushroom Flammulina velutipes. Mycologia 2006, 98, 167-171. [CrossRef]

101. Ngai, P.H.K.; Ng, T.B. A mushroom (Ganoderma capense) lectin with spectacular thermostability, potent mitogenic activity on splenocytes, and antiproliferative activity toward tumor cells. Biochem. Biophys. Res. Commun. 2004, 314, 988-993. [CrossRef]

102. Kawagishi, H.; Nomura, A.; Mizuno, T.; Kimura, A.; Chiba, S. Isolation and characterization of a lectin from Grifola frondosa fruiting bodies. BBA Gen. Subj. 1990, 1034, 247-252. [CrossRef]

103. Pires, A.d.R.A.; Ruthes, A.C.; Cadena, S.M.S.C.; Iacomini, M. Cytotoxic effect of a mannogalactoglucan extracted from Agaricus bisporus on HepG2 cells. Carbohydr. Polym. 2017, 170, 33-42. [CrossRef] [PubMed]

104. Jiang, D.; Wang, L.; Zhao, T.; Zhang, Z.; Zhang, R.; Jin, J.; Cai, Y.; Wang, F. Restoration of the tumor-suppressor function to mutant p53 by Ganoderma lucidum polysaccharides in colorectal cancer cells. Oncol. Rep. 2017, 37, 594-600. [CrossRef] [PubMed]

105. Zhao, X.; Zhou, D.; Liu, Y.; Li, C.; Zhao, X.; Li, Y.; Li, W. Ganoderma lucidum polysaccharide inhibits prostate cancer cell migration via the protein arginine methyltransferase 6 signaling pathway. Mol. Med. Rep. 2018, 17, 147-157. [CrossRef] [PubMed]

106. Wang, C.; Shi, S.; Chen, Q.; Lin, S.; Wang, R.; Wang, S.; Chen, C. Antitumor and immunomodulatory activities of Ganoderma lucidum polysaccharides in glioma-bearing rats. Integr. Cancer Ther. 2018, 17, 674-683. [CrossRef] [PubMed]

107. Zhang, Y.; Sun, D.; Meng, Q.; Guo, W.; Chen, Q.; Zhang, Y. Grifola frondosa polysaccharides induce breast cancer cell apoptosis via the mitochondrial-dependent apoptotic pathway. Int. J. Mol. Med. 2017, 40, 1089-1095. [CrossRef]

108. Liu, J.Y.; Hou, X.X.; Li, Z.Y.; Shan, S.H.; Chang, M.C.; Feng, C.P.; Wei, Y. Isolation and structural characterization of a novel polysaccharide from Hericium erinaceus fruiting bodies and its arrest of cell cycle at S-phage in colon cancer cells. Int. J. Biol. Macromol. 2020, 157, 288-295. [CrossRef]

109. Jeff, I.B.; Fan, E.; Tian, M.; Song, C.; Yan, J.; Zhou, Y. In vivo anticancer and immunomodulating activities of mannogalactoglucantype polysaccharides from Lentinus edodes (Berkeley) singer. Cent. Eur. J. Immunol. 2016, 41, 47-53. [CrossRef] 
110. Ya, G. A Lentinus edodes polysaccharide induces mitochondrial-mediated apoptosis in human cervical carcinoma HeLa cells. Int. J. Biol. Macromol. 2017, 103, 676-682. [CrossRef]

111. Qi, W.; Zhou, X.; Wang, J.; Zhang, K.; Zhou, Y.; Chen, S.; Nie, S.; Xie, M. Cordyceps sinensis polysaccharide inhibits colon cancer cells growth by inducing apoptosis and autophagy flux blockage via mTOR signaling. Carbohydr. Polym. 2020, 237, 116113. [CrossRef] [PubMed]

112. Ren, D.; Wang, N.; Guo, J.; Yuan, L.; Yang, X. Chemical characterization of Pleurotus eryngii polysaccharide and its tumor-inhibitory effects against human hepatoblastoma HepG-2 cells. Carbohydr. Polym. 2016, 138, 123-133. [CrossRef]

113. Uddin Pk, M.; Sayful Islam, M.; Pervin, R.; Dutta, S.; Talukder, R.I.; Rahman, M. Optimization of extraction of antioxidant polysaccharide from Pleurotus ostreatus (Jacq.) P. Kumm and its cytotoxic activity against murine lymphoid cancer cell line. PLoS ONE 2019, 14, e0209371. [CrossRef]

114. Lee, M.S.; Kim, Y.J. Signaling pathways downstream of pattern-recognition receptors and their cross talk. Annu. Rev. Biochem. 2007, 76, 447-480. [CrossRef] [PubMed]

115. Abbas, A.K.; Lichtman, A.H.; Pillai, S. Basic Immunology (6th edition): Functions and Disorders of the Immune System; Elsevier Health Sciences: Amsterdam, The Netherlands, 2019; ISBN 9780323549431.

116. Van de Velde, J.; Wilbers, R.H.P.; Westerhof, L.B.; van Raaij, D.R.; Stavrakaki, I.; Sonnenberg, A.S.; Bakker, J.; Schots, A. Assessing the immunomodulatory potential of high-molecular-weight extracts from mushrooms; an assay based on THP-1 macrophages. J. Sci. Food Agric. 2015, 95, 344-350. [CrossRef] [PubMed]

117. Chan, W.K.; Cheung, C.C.H.; Law, H.K.W.; Lau, Y.L.; Chan, G.C.F. Ganoderma lucidum polysaccharides can induce human monocytic leukemia cells into dendritic cells with immuno-stimulatory function. J. Hematol. Oncol. 2008, 1, 1-12. [CrossRef]

118. Chanput, W.; Reitsma, M.; Kleinjans, L.; Mes, J.J.; Savelkoul, H.F.; Wichers, H.J. $\beta$-Glucans are involved in immune-modulation of THP-1 macrophages. Mol. Nutr. Food Res. 2012, 56, 822-833. [CrossRef]

119. Smiderle, F.R.; Alquini, G.; Tadra-Sfeir, M.Z.; Iacomini, M.; Wichers, H.J.; Van Griensven, L.J.L.D. Agaricus bisporus and Agaricus brasiliensis $(1 \rightarrow 6)-\beta$-d-glucans show immunostimulatory activity on human THP-1 derived macrophages. Carbohydr. Polym. 2013, 94, 91-99. [CrossRef]

120. Ellertsen, L.K.; Hetland, G.; Johnson, E.; Grinde, B. Effect of a medicinal extract from Agaricus blazei Murill on gene expression in a human monocyte cell line as examined by microarrays and immuno assays. Int. Immunopharmacol. 2006, 6, 133-143. [CrossRef]

121. Castro-Alves, V.C.; Gomes, D.; Menolli, N.; Sforça, M.L.; do Nascimento, J.R.O. Characterization and immunomodulatory effects of glucans from Pleurotus albidus, a promising species of mushroom for farming and biomass production. Int. J. Biol. Macromol. 2017, 95, 215-223. [CrossRef]

122. Lin, H.; She, Y.H.; Cassileth, B.R.; Sirotnak, F.; Rundles, S.C. Maitake beta-glucan MD-fraction enhances bone marrow colony formation and reduces doxorubicin toxicity in vitro. Int. Immunopharmacol. 2004, 4, 91-99. [CrossRef] [PubMed]

123. Jin, M.; Jeon, H.; Jung, H.J.; Kim, B.; Shin, S.S.; Choi, J.J.; Lee, J.K.; Kang, C.Y.; Kim, S. Enhancement of repopulation and hematopoiesis of bone marrow cells in irradiated mice by oral administration of PG101, a water-soluble extract from Lentinus lepideus. Exp. Biol. Med. 2003, 228, 759-766. [CrossRef] [PubMed]

124. Wang, S.Y.; Hsu, M.L.; Hsu, H.C.; Tzeng, C.H.; Lee, S.S.; Shiao, M.S.; Ho, C.K. The anti-tumor effect of Ganoderma lucidum is mediated by cytokines released from activated macrophages and T lymphocytes. Int. J. Cancer 1997, 70, 699-705. [CrossRef]

125. Harada, T.; Miura, N.; Adachi, Y.; Nakajima, M.; Yadomae, T.; Ohno, N. Effect of SCG, 1,3- $\beta$-D-Glucan from Sparassis crispa on the hematopoietic response in cyclophosphamide induced leukopenic mice. Biol. Pharm. Bull. 2002, 25, 931-939. [CrossRef]

126. Lu, C.C.; Hsu, Y.J.; Chang, C.J.; Lin, C.S.; Martel, J.; Ojcius, D.M.; Ko, Y.F.; Lai, H.C.; Young, J.D. Immunomodulatory properties of medicinal mushrooms: Differential effects of water and ethanol extracts on NK cell-mediated cytotoxicity. Innate Immun. 2016, 22, 522-533. [CrossRef]

127. Liu, C.; Choi, M.W.; Xue, X.; Cheung, P.C.K. Immunomodulatory effect of structurally-characterized mushroom sclerotial polysaccharides isolated from Polyporus rhinocerus on bone marrow dendritic cells (BMDCs). J. Agric. Food Chem. 2019, 67, 12137-12143. [CrossRef]

128. Liu, C.; Cheung, P.C.K. Structure and immunomodulatory activity of microparticulate mushroom sclerotial $\beta$-Glucan prepared from Polyporus rhinocerus. J. Agric. Food Chem. 2019, 67, 9070-9078. [CrossRef]

129. Ma, Z.; Wang, J.; Zhang, L.; Zhang, Y.; Ding, K. Evaluation of water soluble $\beta$-d-glucan from Auricularia auricular-judae as potential anti-tumor agent. Carbohydr. Polym. 2010, 80, 977-983. [CrossRef]

130. Firenzuoli, F.; Gori, L.; Lombardo, G. The medicinal mushroom Agaricus blazei murrill: Review of literature and pharmacotoxicological problems. Evid.-Based Complement. Altern. Med. 2008, 5, 3-15. [CrossRef]

131. Lutsik-Kordovsky, M.D.; Stasyk, T.V.; Stoika, R.S. Analysis of cytotoxicity of lectin and non-lectin proteins from Amanita mushrooms. Exp. Oncol. 2001, 23, 43-45.

132. Zheng, S.; Li, C.; Ng, T.B.; Wang, H.X. A lectin with mitogenic activity from the edible wild mushroom Boletus edulis. Process Biochem. 2007, 42, 1620-1624. [CrossRef]

133. Yao, H.Y.; Zhang, L.H.; Shen, J.; Shen, H.J.; Jia, Y.L.; Yan, X.F.; Xie, Q.M. Cyptoporus polysaccharide prevents lipopolysaccharideinduced acute lung injury associated with down-regulating Toll-like receptor 2 expression. J. Ethnopharmacol. 2011, 137, 1267-1274. [CrossRef] 
134. Manna, D.; Pust, S.; Torgersen, M.L.; Cordara, G.; Künzler, M.; Krengel, U.; Sandvig, K. Polyporus squamosus Lectin 1a (PSL1a) exhibits cytotoxicity in mammalian cells by disruption of focal adhesions, inhibition of protein synthesis and induction of apoptosis. PLoS ONE 2017, 12, e0170716. [CrossRef] [PubMed]

135. Lin, J.W.; Guan, S.Y.; Duan, Z.W.; Shen, Y.H.; Fan, W.L.; Chen, L.J.; Zhang, L.; Zhang, L.; Li, T.L. Gene cloning of a novel fungal immunomodulatory protein from Chroogomphis rutilus and its expression in Pichia pastoris. J. Chem. Technol. Biotechnol. 2016, 91, 2761-2768. [CrossRef]

136. Li, S.; Jiang, Z.; Sun, L.; Liu, X.; Huang, Y.; Wang, F.; Xin, F. Characterization of a new fungal immunomodulatory protein, FIP-dsq2 from Dichomitus squalens. J. Biotechnol. 2017, 246, 45-51. [CrossRef]

137. Yin, H.; Wang, Y.; Wang, Y.; Chen, T.; Tang, H.; Wang, M. Purification, characterization and immuno-modulating properties of polysaccharides isolated from Flammulina velutipes mycelium. Am. J. Chin. Med. 2010, 38, 191-204. [CrossRef]

138. Wang, P.H.; Hsu, C.I.; Tang, S.C.; Huang, Y.L.; Lin, J.Y.; Ko, J.L. Fungal immunomodulatory protein from Flammulina velutipes induces interferon- $\gamma$ production through p38 mitogen-activated protein kinase signaling pathway. J. Agric. Food Chem. 2004, 52, 2721-2725. [CrossRef]

139. Zhu, X.L.; Chen, A.F.; Lin, Z. Bin Ganoderma lucidum polysaccharides enhance the function of immunological effector cells in immunosuppressed mice. J. Ethnopharmacol. 2007, 111, 219-226. [CrossRef]

140. Matsui, K.; Kodama, N.; Nanba, H. Effects of maitake (Grifola frondosa) D-Fraction on the carcinoma angiogenesis. Cancer Lett. 2001, 172, 193-198. [CrossRef]

141. Pacheco-Sanchez, M.; Boutin, Y.; Angers, P.; Gosselin, A.; Tweddell, R.J. A bioactive $(1 \rightarrow 3)-$, $(1 \rightarrow 4)-\beta$-D-glucan from Collybia dryophila and other mushrooms. Mycologia 2006, 98, 180-185. [CrossRef] [PubMed]

142. Li, Q.; Wang, X.; Chen, Y.; Lin, J.; Zhou, X. Cytokines expression induced by Ganoderma sinensis fungal immunomodulatory proteins (FIP-gsi) in mouse spleen cells. Appl. Biochem. Biotechnol. 2010, 162, 1403-1413. [CrossRef] [PubMed]

143. Lin, C.H.; Hsiao, Y.M.; Ou, C.C.; Lin, Y.W.; Chiu, Y.L.; Lue, K.H.; Chang, J.G.; Ko, J.L. GMI, a Ganoderma immunomodulatory protein, down-regulates tumor necrosis factor $\alpha$-induced expression of matrix metalloproteinase 9 via NF- $\mathrm{kB}$ pathway in human alveolar epithelial A549 cells. J. Agric. Food Chem. 2010, 58, 12014-12021. [CrossRef] [PubMed]

144. Hsiao, Y.M.; Huang, Y.L.; Tang, S.C.; Shieh, G.J.; Lai, J.Y.; Wang, P.H.; Ying, T.H.; Ko, J.L. Effect of a fungal immunomodulatory protein from Ganoderma tsugae on cell cycle and interferon-gamma production through phosphatidylinositol 3-kinase signal pathway. Process Biochem. 2008, 43, 423-430. [CrossRef]

145. Bastiaan-Net, S.; Chanput, W.; Hertz, A.; Zwittink, R.D.; Mes, J.J.; Wichers, H.J. Biochemical and functional characterization of recombinant fungal immunomodulatory proteins (rFIPs). Int. Immunopharmacol. 2013, 15, 167-175. [CrossRef] [PubMed]

146. Li, Q.Z.; Wang, X.F.; Bao, T.W.; Ran, L.; Lin, J.; Zhou, X.W. In vitro synthesis of a recombinant fungal immunomodulatory protein from Lingzhi or Reishi medicinal mushroom, Ganoderma lucidum (W.Curt.:Fr.) P.Karst. (Aphyllophoromycetideae) and analysis of its immunomodulatory activity. Int. J. Med. Mushrooms 2010, 12, 347-358. [CrossRef]

147. Lee, J.S.; Cho, J.Y.; Hong, E.K. Study on macrophage activation and structural characteristics of purified polysaccharides from the liquid culture broth of Hericium erinaceus. Carbohydr. Polym. 2009, 78, 162-168. [CrossRef]

148. Won, D.P.; Lee, J.S.; Kwon, D.S.; Lee, K.E.; Shin, W.C.; Hong, E.K. Immunostimulating activity by polysaccharides isolated from fruiting body of Inonotus obliquus. Mol. Cells 2011, 31, 165-173. [CrossRef]

149. Cong, W.R.; Xu, H.; Liu, Y.; Li, Q.Z.; Li, W.; Zhou, X.W. Production and functional characterization of a novel fungal immunomodulatory protein FIP-SN15 shuffled from two genes of Ganoderma species. Appl. Microbiol. Biotechnol. 2014, 98, 5967-5975. [CrossRef]

150. Koyama, Y.; Katsuno, Y.; Miyoshi, N.; Hayakawa, S.; Mita, T.; Muto, H.; Isemura, S.; Aoyagi, Y.; Isemura, M. Apoptosis induction by lectin isolated from the mushroom Boletopsis leucomelas in U937 cells. Biosci. Biotechnol. Biochem. 2002, 66, 784-789. [CrossRef]

151. Morales, D.; Rutckeviski, R.; Villalva, M.; Abreu, H.; Soler-Rivas, C.; Santoyo, S.; Iacomini, M.; Smiderle, F.R. Isolation and comparison of $\alpha$ - and $\beta$-D-glucans from shiitake mushrooms (Lentinula edodes) with different biological activities. Carbohydr. Polym. 2020, 229, 115521. [CrossRef] [PubMed]

152. Bhunia, S.K.; Dey, B.; Maity, K.K.; Patra, S.; Mandal, S.; Maiti, S.; Maiti, T.K.; Sikdar, S.R.; Islam, S.S. Isolation and characterization of an immunoenhancing glucan from alkaline extract of an edible mushroom, Lentinus squarrosulus (Mont.) Singer. Carbohydr. Res. 2011, 346, 2039-2044. [CrossRef]

153. Pushparajah, V.; Fatima, A.; Chong, C.H.; Gambule, T.Z.; Chan, C.J.; Ng, S.T.; Tan, C.S.; Fung, S.Y.; Lee, S.S.; Tan, N.H.; et al. Characterisation of a new fungal immunomodulatory protein from tiger milk mushroom, Lignosus rhinocerotis. Sci. Rep. 2016, 6, 30010. [CrossRef]

154. Wu, Y.; Wang, H.; Ng, T.B. Purification and characterization of a lectin with antiproliferative activity toward cancer cells from the dried fruit bodies of Lactarius flavidulus. Carbohydr. Res. 2011, 346, 2576-2581. [CrossRef]

155. Wang, H.X.; Ng, T.B.; Ooi, V.E.C.; Liu, W.K.; Chang, S.T. Actions of lectins from the mushroom Tricholoma mongolicum on macrophages, splenocytes and life-span in sarcoma-bearing mice. Anticancer Res. 1997, 17, 419-424.

156. Ooi, V.E.C. Pharmacological studies on certain mushrooms from China. Int. J. Med. Mushrooms 2001, 3, 341-354. [CrossRef]

157. Cordara, G.; Winter, H.C.; Goldstein, I.J.; Krengel, U.; Sandvig, K. The fungal chimerolectin MOA inhibits protein and DNA synthesis in NIH/3T3 cells and may induce BAX-mediated apoptosis. Biochem. Biophys. Res. Commun. 2014, 447, 586-589. [CrossRef] [PubMed]

158. Cui, H.L.; Chen, Y.; Wang, S.S.; Kai, G.Q.; Fang, Y.M. Isolation, partial characterisation and immunomodulatory activities of polysaccharide from Morchella esculenta. J. Sci. Food Agric. 2011, 91, 2180-2185. [CrossRef] 
159. Su, C.A.; Xu, X.Y.; Liu, D.Y.; Wu, M.; Zeng, F.Q.; Zeng, M.Y.; Wei, W.; Jiang, N.; Luo, X. Isolation and characterization of exopolysaccharide with immunomodulatory activity from fermentation broth of Morchella conica. DARU J. Pharm. Sci. 2013, 21, 5. [CrossRef] [PubMed]

160. Du, X.J.; Zhang, J.S.; Yang, Y.; Tang, Q.J.; Jia, W.; Pan, Y.J. Purification, chemical modification and immunostimulating activity of polysaccharides from Tremella aurantialba fruit bodies. J. Zhejiang Univ. Sci. B 2010, 11, 437-442. [CrossRef] [PubMed]

161. Roy, S.K.; Das, D.; Mondal, S.; Maiti, D.; Bhunia, B.; Maiti, T.K.; Islam, S.S. Structural studies of an immunoenhancing watersoluble glucan isolated from hot water extract of an edible mushroom, Pleurotus florida, cultivar Assam Florida. Carbohydr. Res. 2009, 344, 2596-2601. [CrossRef] [PubMed]

162. Chen, X.; Xu, X.; Zhang, L.; Kennedy, J.F. Flexible chain conformation of $(1 \rightarrow 3)$ - $\beta$-d-glucan from Poria cocos sclerotium in $\mathrm{NaOH} /$ urea aqueous solution. Carbohydr. Polym. 2009, 75, 586-591. [CrossRef]

163. Gern, R.M.M.; Wisbeck, E.; Rampinelli, J.R.; Ninow, J.L.; Furlan, S.A. Alternative medium for production of Pleurotus ostreatus biomass and potential antitumor polysaccharides. Bioresour. Technol. 2008, 99, 76-82. [CrossRef] [PubMed]

164. Zhao, J.K.; Wang, H.X.; Ng, T.B. Purification and characterization of a novel lectin from the toxic wild mushroom Inocybe umbrinella. Toxicon 2009, 53, 360-366. [CrossRef]

165. Mahajan, R.G.; Patil, S.I.; Mohan, D.R.K.; Shastry, P. Pleurotus eous mushroom lectin (PEL) with mixed carbohydrate inhibition and antiproliferative activity on tumor cell lines. J. Biochem. Mol. Biol. Biophys. 2002, 6, 341-345. [CrossRef]

166. Li, S.Y.; Shi, L.J.; Ding, Y.; Nie, Y.; Tang, X.M. Identification and functional characterization of a novel fungal immunomodulatory protein from Postia placenta. Food Chem. Toxicol. 2015, 78, 64-70. [CrossRef]

167. Chang, H.; Sheu, F. A novel fungal immunomodulatory protein (PCP) isolated from Poria cocos activates mouse peritoneal macrophage involved in toll-like receptor 4. FASEB J. 2007, 21, A738. [CrossRef]

168. Zhang, G.; Sun, J.; Wang, H.; Ng, T.B. First isolation and characterization of a novel lectin with potent antitumor activity from a Russula mushroom. Phytomedicine 2010, 17, 775-781. [CrossRef] [PubMed]

169. Hobbs, C.R. The chemistry, nutritional value, immunopharmacology, and safety of the traditional food of medicinal split-gill fugus Schizophyllum commune Fr.:Fr. (Schizophyllaceae). A literature review. Int. J. Med. Mushrooms 2005, 7, 127-140. [CrossRef]

170. Bimczok, D.; Wrenger, J.; Schirrmann, T.; Rothkötter, H.J.; Wray, V.; Rau, U. Short chain regioselectively hydrolyzed scleroglucans induce maturation of porcine dendritic cells. Appl. Microbiol. Biotechnol. 2009, 82, 321-331. [CrossRef]

171. Han, X.Q.; Wu, X.M.; Chai, X.Y.; Chen, D.; Dai, H.; Dong, H.L.; Ma, Z.Z.; Gao, X.M.; Tu, P.F. Isolation, characterization and immunological activity of a polysaccharide from the fruit bodies of an edible mushroom, Sarcodon aspratus (Berk.) S. Ito. Food Res. Int. 2011, 44, 489-493. [CrossRef]

172. Han, C.H.; Liu, Q.H.; Ng, T.B.; Wang, H.X. A novel homodimeric lactose-binding lectin from the edible split gill medicinal mushroom Schizophyllum commune. Biochem. Biophys. Res. Commun. 2005, 336, 252-257. [CrossRef] [PubMed]

173. Zhang, W.; Tian, G.; Geng, X.; Zhao, Y.; Ng, T.B.; Zhao, L.; Wang, H. Isolation and characterization of a novel lectin from the edible mushroom Stropharia rugosoannulata. Molecules 2014, 19, 19880-19891. [CrossRef]

174. Rau, U.; Kuenz, A.; Wray, V.; Nimtz, M.; Wrenger, J.; Cicek, H. Production and structural analysis of the polysaccharide secreted by Trametes (Coriolus) versicolor ATCC 200801. Appl. Microbiol. Biotechnol. 2009, 81, 827-837. [CrossRef] [PubMed]

175. Liu, J.J.; Huang, T.S.; Hsu, M.L.; Chen, C.C.; Lin, W.S.; Lu, F.J.; Chang, W.H. Antitumor effects of the partially purified polysaccharides from Antrodia camphorata and the mechanism of its action. Toxicol. Appl. Pharmacol. 2004, 201, 186-193. [CrossRef]

176. Wu, S.J.; Liaw, C.C.; Pan, S.Z.; Yang, H.C.; Ng, L.T. Phellinus linteus polysaccharides and their immunomodulatory properties in human monocytic cells. J. Funct. Foods 2013, 5, 679-688. [CrossRef]

177. Wasser, S. Medicinal mushrooms as a source of antitumor and immunomodulating polysaccharides. Appl. Microbiol. Biotechnol. 2002, 60, 258-274. [PubMed]

178. Sheu, F.; Chien, P.J.; Hsieh, K.Y.; Chin, K.L.; Huang, W.T.; Tsao, C.Y.; Chen, Y.F.; Cheng, H.C.; Chang, H.H. Purification, cloning, and functional characterization of a novel immunomodulatory protein from Antrodia camphorata (Bitter Mushroom) that exhibits TLR2-dependent NF-kB activation and M1 polarization within murine macrophages. J. Agric. Food Chem. 2009, 57, $4130-4141$. [CrossRef]

179. Li, F.; Wen, H.A.; Zhang, Y.J.; An, M.; Liu, X.Z. Purification and characterization of a novel immunomodulatory protein from the medicinal mushroom Trametes versicolor. Sci. China Life Sci. 2011, 54, 379-385. [CrossRef]

180. Hsu, H.Y.; Hua, K.F.; Wu, W.C.; Hsu, J.; Weng, S.T.; Lin, T.L.; Liu, C.Y.; Hseu, R.S.; Huang, C.T. Reishi immuno-modulation protein induces interleukin-2 expression via protein kinase-dependent signaling pathways within human T cells. J. Cell. Physiol. 2008, 215, 15-26. [CrossRef]

181. Ko, H.J.; Song, A.; Lai, M.N.; Ng, L.T. Immunomodulatory properties of Xylaria nigripes in peritoneal macrophage cells of Balb/c mice. J. Ethnopharmacol. 2011, 138, 762-768. [CrossRef]

182. Marty-Detraves, C.; Francis, F.; Baricault, L.; Fournier, D.; Paquereau, L. Inhibitory action of a new lectin from Xerocomus chrysenteron on cell-substrate adhesion. Mol. Cell. Biochem. 2004, 258, 49-55. [CrossRef] [PubMed]

183. Liu, Q.; Wang, H.; Ng, T.B. First report of a xylose-specific lectin with potent hemagglutinating, antiproliferative and anti-mitogenic activities from a wild ascomycete mushroom. Biochim. Biophys. Acta Gen. Subj. 2006, 1760, 1914-1919. [CrossRef] [PubMed]

184. Vamanu, E. Antioxidant properties of mushroom mycelia obtained by batch cultivation and tocopherol content affected by extraction procedures. BioMed Res. Int. 2014, 2014, 974804. [CrossRef] 
185. Boonsong, S.; Klaypradit, W.; Wilaipun, P. Antioxidant activities of extracts from five edible mushrooms using different extractants. Agric. Nat. Resour. 2016, 50, 89-97. [CrossRef]

186. Cheung, L.M.; Cheung, P.C.K.; Ooi, V.E.C. Antioxidant activity and total phenolics of edible mushroom extracts. Food Chem. 2003, 81, 249-255. [CrossRef]

187. Yoon, K.N.; Alam, N.; Lee, K.R.; Shin, P.G.; Cheong, J.C.; Yoo, Y.B.; Lee, T.S. Antioxidant and antityrosinase activities of various extracts from the fruiting bodies of Lentinus lepideus. Molecules 2011, 16, 2334-2347. [CrossRef] [PubMed]

188. Im, K.H.; Nguyen, T.K.; Shin, D.B.; Lee, K.R.; Lee, T.S. Appraisal of antioxidant and anti-inflammatory activities of various extracts from the fruiting bodies of Pleurotus florida. Molecules 2014, 19, 3310-3326. [CrossRef]

189. Xu, D.P.; Zheng, J.; Zhou, Y.; Li, Y.; Li, S.; Li, H. Bin Extraction of natural antioxidants from the Thelephora ganbajun mushroom by an ultrasound-assisted extraction technique and evaluation of antiproliferative activity of the extract against human cancer cells. Int. J. Mol. Sci. 2016, 17, 1664. [CrossRef]

190. Wang, Y.; Jia, J.; Ren, X.; Li, B.; Zhang, Q. Extraction, preliminary characterization and in vitro antioxidant activity of polysaccharides from Oudemansiella radicata mushroom. Int. J. Biol. Macromol. 2018, 120, 1760-1769. [CrossRef] [PubMed]

191. Si, J.; Meng, G.; Wu, Y.; Ma, H.F.; Cui, B.K.; Dai, Y.C. Medium composition optimization, structural characterization, and antioxidant activity of exopolysaccharides from the medicinal mushroom Ganoderma lingzhi. Int. J. Biol. Macromol. 2019, 124, 1186-1196. [CrossRef] [PubMed]

192. Matijašević, D.; Pantić, M.; Rašković, B.; Pavlović, V.; Duvnjak, D.; Sknepnek, A.; Nikšić, M. The Antibacterial activity of Coriolus versicolor methanol extract and its effect on ultrastructural changes of Staphylococcus aureus and Salmonella enteritidis. Front. Microbiol. 2016, 7, 1226. [CrossRef] [PubMed]

193. Janeš, D.; Kreft, S.; Jurc, M.; Seme, K.; Štrukelj, B. Antibacterial activity in higher fungi (Mushrooms) and endophytic fungi from Slovenia. Pharm. Biol. 2008, 45, 700-706. [CrossRef]

194. Kombrink, A.; Tayyrov, A.; Essig, A.; Stöckli, M.; Micheller, S.; Hintze, J.; van Heuvel, Y.; Dürig, N.; Lin, C.; Kallio, P.T.; et al. Induction of antibacterial proteins and peptides in the coprophilous mushroom Coprinopsis cinerea in response to bacteria. ISME J. 2019, 13, 588-602. [CrossRef] [PubMed]

195. Sharma, S.K.; Gautam, N. Evaluation of nutritional, nutraceutical, and antioxidant composition of eight wild culinary mushrooms (higher basidiomycetes) from the northwest Himalayas. Int. J. Med. Mushrooms 2016, 18, 539-546. [CrossRef]

196. Barros, L.; Falcão, S.; Baptista, P.; Freire, C.; Vilas-Boas, M.; Ferreira, I.C.F.R. Antioxidant activity of Agaricus sp. mushrooms by chemical, biochemical and electrochemical assays. Food Chem. 2008, 111, 61-66. [CrossRef]

197. Ghahremani-Majd, H.; Dashti, F. Chemical composition and antioxidant properties of cultivated button mushrooms (Agaricus bisporus). Hortic. Environ. Biotechnol. 2015, 56, 376-382. [CrossRef]

198. Robaszkiewicz, A.; Bartosz, G.; Ławrynowicz, M.; Soszyński, M. The role of polyphenols, $\beta$-carotene, and lycopene in the antioxidative action of the extracts of dried, edible mushrooms. J. Nutr. Metab. 2010, 2010, 173274. [CrossRef] [PubMed]

199. Kozarski, M.; Klaus, A.; Niksic, M.; Jakovljevic, D.; Helsper, J.P.F.G.; Van Griensven, L.J.L.D. Antioxidative and immunomodulating activities of polysaccharide extracts of the medicinal mushrooms Agaricus bisporus, Agaricus brasiliensis, Ganoderma lucidum and Phellinus linteus. Food Chem. 2011, 129, 1667-1675. [CrossRef]

200. Wu, S.; Li, F.; Jia, S.; Ren, H.; Gong, G.; Wang, Y.; Lv, Z.; Liu, Y. Drying effects on the antioxidant properties of polysaccharides obtained from Agaricus blazei Murrill. Carbohydr. Polym. 2014, 103, 414-417. [CrossRef] [PubMed]

201. Jia, S.; Li, F.; Liu, Y.; Ren, H.; Gong, G.; Wang, Y.; Wu, S. Effects of extraction methods on the antioxidant activities of polysaccharides from Agaricus blazei Murrill. Int. J. Biol. Macromol. 2013, 62, 66-69. [CrossRef]

202. Carneiro, A.A.J.; Ferreira, I.C.F.R.; Dueñas, M.; Barros, L.; Da Silva, R.; Gomes, E.; Santos-Buelga, C. Chemical composition and antioxidant activity of dried powder formulations of Agaricus blazei and Lentinus edodes. Food Chem. 2013, 138, 2168-2173. [CrossRef]

203. Barros, L.; Dueñas, M.; Ferreira, I.C.F.R.; Baptista, P.; Santos-Buelga, C. Phenolic acids determination by HPLC-DAD-ESI/MS in sixteen different Portuguese wild mushrooms species. Food Chem. Toxicol. 2009, 47, 1076-1079. [CrossRef]

204. Heleno, S.A.; Barros, L.; Sousa, M.J.; Martins, A.; Ferreira, I.C.F.R. Tocopherols composition of Portuguese wild mushrooms with antioxidant capacity. Food Chem. 2010, 119, 1443-1450. [CrossRef]

205. Gasecka, M.; Magdziak, Z.; Siwulski, M.; Mleczek, M. Profile of phenolic and organic acids, antioxidant properties and ergosterol content in cultivated and wild growing species of Agaricus. Eur. Food Res. Technol. 2018, 244, 259-268. [CrossRef]

206. Garrab, M.; Edziri, H.; El Mokni, R.; Mastouri, M.; Mabrouk, H.; Douki, W. Phenolic composition, antioxidant and anticholinesterase properties of the three mushrooms Agaricus silvaticus Schaeff., Hydnum rufescens Pers. and Meripilus giganteus (Pers.) Karst. in Tunisia. S. Afr. J. Bot. 2019, 124, 359-363. [CrossRef]

207. Ribeiro, B.; de Pinho, P.G.; Andrade, P.B.; Oliveira, C.; Ferreira, A.C.S.; Baptista, P.; Valentão, P. Do bioactive carotenoids contribute to the color of edible mushrooms? Open Chem. Biomed. Methods J. 2011, 4, 14-18. [CrossRef]

208. Öztürk, M.; Duru, M.E.; Kivrak, S..; Mercan-Doĝan, N.; Türkoglu, A.; Özler, M.A. In vitro antioxidant, anticholinesterase and antimicrobial activity studies on three Agaricus species with fatty acid compositions and iron contents: A comparative study on the three most edible mushrooms. Food Chem. Toxicol. 2011, 49, 1353-1360. [CrossRef] [PubMed]

209. Buruleanu, L.C.; Radulescu, C.; Antonia Georgescu, A.; Dulama, I.D.; Nicolescu, C.M.; Lucian Olteanu, R.; Stanescu, S.G. Chemometric assessment of the interactions between the metal contents, antioxidant activity, total phenolics, and flavonoids in mushrooms. Anal. Lett. 2019, 52, 1195-1214. [CrossRef] 
210. Kouassi, K.A.; Kouadio, E.J.P.; Konan, K.H.; Dué, A.E.; Kouamé, L.P. Phenolic compounds, organic acid and antioxidant activity of Lactarius subsericatus, Cantharellus platyphyllus and Amanita rubescens, three edible ectomycorrhizal mushrooms from center of Côte d'Ivoire. Eurasian J. Anal. Chem. 2016, 11, 127-139.

211. Lai, M.N.; Ng, L.T. Antioxidant and antiedema properties of solid-state cultured honey mushroom, Armillaria mellea (Higher Basidiomycetes), extracts and their polysaccharide and polyphenol contents. Int. J. Med. Mushrooms 2013, 15, 1-8. [CrossRef]

212. Muszyńska, B.; Sułkowska-Ziaja, K.; Ekiert, H. Phenolic acids in selected edible basidiomycota species: Armillaria mellea, Boletus badius, Boletus edulis, Cantharellus cibarius, Lactarius deliciosus and Pleurotus ostreatus. Acta Sci. Pol. Hortorum Cultus 2013, 12, $107-116$.

213. Strapáč, I.; Baranová, M.; Smrčová, M.; Bedlovičová, Z. Antioxidant activity of honey mushrooms (Armillaria mellea). Folia Vet. 2016, 60, 37-41. [CrossRef]

214. Keleş, A.; Koca, I.; Gençcelep, H. Antioxidant properties of wild Edible mushrooms. J. Food Process. Technol. $2011,2,2-6$.

215. Cai, M.; Lin, Y.; Luo, Y.L.; Liang, H.H.; Sun, P.L. Extraction, antimicrobial, and antioxidant activities of crude polysaccharides from the wood ear medicinal mushroom Auricularia auricula-judae (higher basidiomycetes). Int. J. Med. Mushrooms 2015, 17, 591-600. [CrossRef]

216. Kho, Y.S.; Vikineswary, S.; Abdullah, N.; Kuppusamy, U.R.; Oh, H.I. Antioxidant capacity of fresh and processed fruit bodies and mycelium of Auricularia auricula-judae (Fr.) quél. J. Med. Food 2009, 12, 167-174. [CrossRef] [PubMed]

217. Yu, S.C.; Oh, T.J. Antioxidant activities and antimicrobial effects of extracts from Auricularia auricula-judae. J. Korean Soc. Food Sci. Nutr. 2016, 45, 327-332. [CrossRef]

218. Teoh, H.L.; Ahmad, I.S.; Johari, N.M.K.; Aminudin, N.; Abdullah, N. Antioxidant properties and yield of wood ear Mushroom, Auricularia polytricha (Agaricomycetes), cultivated on rubberwood sawdust. Int. J. Med. Mushrooms 2018, 20, 369-380. [CrossRef]

219. Bai, S.; Zhang, X.; Ma, X.; Chen, J.; Chen, Q.; Shi, X.; Hou, M.; Xue, P.; Kang, Y.; Xu, Z. Acid-active supramolecular anticancer nanoparticles based on cyclodextrin polyrotaxanes damaging both mitochondria and nuclei of tumor cells. Biomater. Sci. 2018, 6 , 3126-3138. [CrossRef]

220. Sun, L.; Bai, X.; Zhuang, Y. Effect of different cooking methods on total phenolic contents and antioxidant activities of four Boletus mushrooms. J. Food Sci. Technol. 2014, 51, 3362-3368. [CrossRef]

221. Jaworska, G.; Pogoń, K.; Skrzypczak, A.; Bernaś, E. Composition and antioxidant properties of wild mushrooms Boletus edulis and Xerocomus badius prepared for consumption. J. Food Sci. Technol. 2015, 52, 7944-7953. [CrossRef]

222. Zhang, A.; Xiao, N.; He, P.; Sun, P. Chemical analysis and antioxidant activity in vitro of polysaccharides extracted from Boletus edulis. Int. J. Biol. Macromol. 2011, 49, 1092-1095. [CrossRef] [PubMed]

223. Vamanu, E.; Nita, S. Antioxidant capacity and the correlation with major phenolic compounds, anthocyanin, and tocopherol content in various extracts from the wild edible Boletus edulis mushroom. BioMed Res. Int. 2013, 2013, 313905. [CrossRef] [PubMed]

224. Vaz, J.A.; Barros, L.; Martins, A.; Santos-Buelga, C.; Vasconcelos, M.H.; Ferreira, I.C.F.R. Chemical composition of wild edible mushrooms and antioxidant properties of their water soluble polysaccharidic and ethanolic fractions. Food Chem. 2011, 126, 610-616. [CrossRef]

225. Vamanu, E.; Nita, S. Bioactive compounds, antioxidant and anti-inflammatory activities of extracts from Cantharellus cibarius. Rev. Chim. 2014, 65, 372-379.

226. Ebrahimzadeh, M.A.; Safdari, Y.; Khalili, M. Antioxidant activity of different fractions of methanolic extract of the golden chanterelle mushroom Cantharellus cibarius (higher basidiomycetes) from Iran. Int. J. Med. Mushrooms 2015, 17, 557-565. [CrossRef] [PubMed]

227. Zhao, D.; Ding, X.; Hou, Y.; Hou, W.; Liu, L.; Xu, T.; Yang, D. Structural characterization, immune regulation and antioxidant activity of a new heteropolysaccharide from Cantharellus cibarius Fr. Int. J. Mol. Med. 2018, 41, 2744-2754. [CrossRef]

228. Palacios, I.; Lozano, M.; Moro, C.; D’Arrigo, M.; Rostagno, M.A.; Martínez, J.A.; García-Lafuente, A.; Guillamón, E.; Villares, A. Antioxidant properties of phenolic compounds occurring in edible mushrooms. Food Chem. 2011, 128, 674-678. [CrossRef]

229. Barreira, J.C.M.; Ferreira, I.C.F.R.; Oliveira, M.B.P.P. Triacylglycerol profile as a chemical fingerprint of mushroom species: Evaluation by principal component and linear discriminant analyses. J. Agric. Food Chem. 2012, 60, 10592-10599. [CrossRef]

230. Šíma, J.; Vondruška, J.; Svoboda, L.; Šeda, M.; Rokos, L. The accumulation of risk and essential elements in edible mushrooms Chlorophyllum rhacodes, Suillus grevillei, Imleria badia, and Xerocomellus chrysenteron growing in the Czech Republic. Chem. Biodivers. 2019, 16, e1800478.

231. Sharma, S.K.; Gautam, N. Chemical and bioactive profiling, and biological activities of coral fungi from northwestern Himalayas. Sci. Rep. 2017, 7, 46570. [CrossRef] [PubMed]

232. Kumari, B.; Upadhyay, R.C.; Atri, N.S. Evaluation of nutraceutical components and antioxidant potential of north indian wild culinarymedicinal termitophilous mushrooms. Int. J. Med. Mushrooms 2013, 15, 191-197. [CrossRef] [PubMed]

233. Vaz, J.A.; Heleno, S.A.; Martins, A.; Almeida, G.M.; Vasconcelos, M.H.; Ferreira, I.C.F.R. Wild mushrooms Clitocybe alexandri and Lepista inversa: In vitro antioxidant activity and growth inhibition of human tumour cell lines. Food Chem. Toxicol. 2010, 48, 2881-2884. [CrossRef] [PubMed]

234. Ersel, F.Y.; Cavas, L. Enzyme-based scavengers and lipid peroxidation in some wild edible Agaricales s.l. mushrooms from Mugla (Turkey). Int. J. Med. Mushrooms 2008, 10, 269-277. [CrossRef]

235. Sarikurkcu, C.; Tepe, B.; Semiz, D.K.; Solak, M.H. Evaluation of metal concentration and antioxidant activity of three edible mushrooms from Mugla, Turkey. Food Chem. Toxicol. 2010, 48, 1230-1233. [CrossRef] 
236. Kosanić, M.; Petrović, N.; Stanojković, T. Bioactive properties of Clitocybe geotropa and Clitocybe nebularis. J. Food Meas. Charact. 2020, 14, 1046-1053. [CrossRef]

237. Schüffler, A. Secondary metabolites of basidiomycetes. In Physiology and Genetics the Mycota (A Comprehensive Treatise on Fungi as Experimental Systems for Basic and Applied Research); Anke, T., Schüffler, A., Eds.; Springer: Cham, Switzerland, 2018; pp. 231-275. ISBN 978-3-319-71739-5.

238. Heleno, S.A.; Ferreira, I.C.F.R.; Calhelha, R.C.; Esteves, A.P.; Martins, A.; Queiroz, M.J.R.P. Cytotoxicity of Coprinopsis atramentaria extract, organic acids and their synthesized methylated and glucuronate derivatives. Food Res. Int. 2014, 55, 170-175. [CrossRef]

239. Stilinović, N.; Čapo, I.; Vukmirović, S.; Rašković, A.; Tomas, A.; Popović, M.; Sabo, A. Chemical composition, nutritional profile and in vivo antioxidant properties of the cultivated mushroom Coprinus comatus. R. Soc. Open Sci. 2020, 7, 200900. [CrossRef] [PubMed]

240. Scuto, M.; Di Mauro, P.; Ontario, M.L.; Amato, C.; Modafferi, S.; Ciavardelli, D.; Salinaro, A.T.; Maiolino, L.; Calabrese, V. Nutritional mushroom treatment in meniere's disease with Coriolus versicolor: A rationale for therapeutic intervention in neuroinflammation and antineurodegeneration. Int. J. Mol. Sci. 2020, 21, 284. [CrossRef]

241. Stojanova, M.; Pantić, M.; Karadelev, M.; Čuleva, B.; Nikšić, M. Antioxidant potential of extracts of three mushroom species collected from the Republic of North Macedonia. J. Food Process. Preserv. 2021, 45, e15155. [CrossRef]

242. Kozarski, M.; Klaus, A.; Vunduk, J.; Nikšić, M. The influence of mushroom Coriolus versicolor and hazelnuts enrichment on antioxidant activities and bioactive content of dark chocolate. Food Feed Res. 2020, 47, 23-32. [CrossRef]

243. Costea, T.; Hudiţă, A.; Olaru, O.T.; Gălăţeanu, B.; Gîrd, C.E.; Mocanu, M.M. Chemical composition, antioxidant activity and cytotoxic effects of romanian Craterellus cornucopioides (L.) pers. mushroom. Farmacia 2020, 68, 340-347. [CrossRef]

244. Liu, T.; Zang, N.; Zhou, N.; Li, W.; Xie, X.; Deng, Y.; Ren, L.; Long, X.; Li, S.; Zhou, L.; et al. Resveratrol inhibits the TRIF-dependent pathway by upregulating sterile alpha and armadillo motif protein, contributing to anti-inflammatory effects after respiratory syncytial virus infection. J. Virol. 2014, 88, 4229-4236. [CrossRef]

245. Kosanić, M.; Ranković, B.; Stanojković, T.; Radović-Jakovljević, M.; Ćirić, A.; Grujičić, D.; Milošević-Djordjević, O. Craterellus cornucopioides edible mushroom as source of biologically active compounds. Nat. Prod. Commun. 2019, 14, 1-6. [CrossRef]

246. Liu, Y.; Duan, X.; Zhang, M.; Li, C.; Zhang, Z.; Liu, A.; Hu, B.; He, J.; Wu, D.; Chen, H.; et al. Cooking methods effect on the nutrients, bioaccessibility and antioxidant activity of Craterellus cornucopioides. LWT 2020, 131, 109768. [CrossRef]

247. Velygodska, A.K.; Fedotov, O.V. The production and analysis of carotenoid preparations from some strains of xylotrophic Basidiomycetes. Biosyst. Divers. 2016, 24, 290-294. [CrossRef]

248. Vaz, J.A.; Barros, L.; Martins, A.; Morais, J.S.; Vasconcelos, M.H.; Ferreira, I.C.F.R. Phenolic profile of seventeen Portuguese wild mushrooms. LWT Food Sci. Technol. 2011, 44, 343-346. [CrossRef]

249. Krüzselyi, D.; Móricz, Á.M.; Vetter, J. Comparison of different morphological mushroom parts based on the antioxidant activity. LWT 2020, 127, 109436. [CrossRef]

250. Ukaegbu, C.I.; Shah, S.R.; Hamid, H.A.; Alara, O.R.; Sarker, M.Z.I. Phenolic compounds of aqueous and methanol extracts of Hypsizygus tessellatus (brown and white var.) and Flammulina velutipes caps: Antioxidant and antiproliferative activities. Pharm. Chem. J. 2020, 54, 170-183. [CrossRef]

251. Payamnoor, V.; Kavosi, M.R.; Nazari, J. Polypore fungi of Caucasian alder as a source of antioxidant and antitumor agents. J. For. Res. 2020, 31, 1381-1390. [CrossRef]

252. Mohammadifar, S.; Gharaghoz, S.F.; Shayan, M.R.A.; Vaziri, A. Comparison between antioxidant activity and bioactive compounds of Ganoderma applanatum (Pers.) Pat. and Ganoderma lucidum (Curt.) P. Karst from Iran. Iran. J. Plant Physiol. 2020, 11, 3417-3424.

253. Xu, Y.; Zhang, X.; Yan, X.H.; Zhang, J.L.; Wang, L.Y.; Xue, H.; Jiang, G.C.; Ma, X.T.; Liu, X.J. Characterization, hypolipidemic and antioxidant activities of degraded polysaccharides from Ganoderma lucidum. Int. J. Biol. Macromol. 2019, 135, 706-716. [CrossRef]

254. Cör, D.; Knez, Ž.; Hrnčič, M.K. Antitumour, antimicrobial, antioxidant and antiacetylcholinesterase effect of Ganoderma Lucidum terpenoids and polysaccharides: A review. Molecules 2018, 23, 649. [CrossRef]

255. Uddin Pk, M.; Talukder, R.I.; Sarkar, M.K.I.; Rahman, T.; Pervin, R.; Rahman, M.; Zenat, E.A.; Akther, L. Effect of solvents on phytochemicals content and antioxidant activity of Ganoderma lucidum. Open Microbiol. J. 2019, 13, 10-15. [CrossRef]

256. Ribeiro, B.; Valentão, P.; Baptista, P.; Seabra, R.M.; Andrade, P.B. Phenolic compounds, organic acids profiles and antioxidative properties of beefsteak fungus (Fistulina hepatica). Food Chem. Toxicol. 2007, 45, 805-813. [CrossRef] [PubMed]

257. Mau, J.L.; Tsai, S.Y.; Tseng, Y.H.; Huang, S.J. Antioxidant properties of hot water extracts from Ganoderma tsugae Murrill. LWT Food Sci. Technol. 2005, 38, 589-597. [CrossRef]

258. Ding, X.; Hou, Y.; Zhu, Y.; Wang, P.; Fu, L.; Zhu, H.; Zhang, N.; Qin, H.; Qu, W.; Wang, F.; et al. Structure elucidation, anticancer and antioxidant activities of a novel polysaccharide from Gomphus clavatus Gray. Oncol. Rep. 2015, 33, 3162-3170. [CrossRef]

259. Makropoulou, M.; Aligiannis, N.; Gonou-Zagou, Z.; Pratsinis, H.; Skaltsounis, A.L.; Fokialakis, N. Antioxidant and cytotoxic activity of the wild edible mushroom Gomphus clavatus. J. Med. Food 2012, 15, 216-221. [CrossRef]

260. Zhang, J.C.; Kong, X.H.; Zhang, P.Q.; Liu, J.N.; Ma, Y.P.; Dai, X.D.; Han, Z.H.; Ma, Q.F.; Wang, X.Y.; Yu, L.P. Identification of a new fungal pathogen causing white villous disease on the fruiting body of the culinary-medicinal mushroom Auricularia auricula-judae (Agaricomycetes) in China. Int. J. Med. Mushrooms 2017, 19, 155-161. [CrossRef] [PubMed]

261. Kaul, S.; Choudhary, M.; Gupta, S.; Agrawal, D.C.; Dhar, M.K. Diversity and medicinal value of mushrooms from the Himalayan region, India. In Medicinal Mushrooms; Agrawal, D.C., Dhanasekaran, M., Eds.; Springer: Singapore, 2019; pp. 371-389. ISBN 978-981-13-6381-8. 
262. Lew, S.Y.; Yow, Y.Y.; Lim, L.W.; Wong, K.H. Antioxidant-mediated protective role of Hericium erinaceus (Bull.: Fr.) pers. against oxidative damage in fibroblasts from friedreich's ataxia patient. Food Sci. Technol. 2020, 40, 264-272. [CrossRef]

263. Tubić, J.; Grujičić, D.; Jakovljević, M.R.; Ranković, B.; Kosanić, M.; Stanojković, T.; Ćirić, A.; Milošević-Djordjević, O. Investigation of biological activities and secondary metabolites of Hydnum repandum acetone extract. Farmacia 2019, 67, 174-183. [CrossRef]

264. Bakir, T.K.; Boufars, M.; Karadeniz, M.; Unal, S. Amino acid composition and antioxidant properties of five edible mushroom species from Kastamonu, Turkey. Afr. J. Tradit. Complement. Altern. Med. 2018, 15, 80-87.

265. Ahmad, A.; Abuzinadah, M.; Alkreathy, H.; Kutbi, H.; Shaik, N.; Ahmad, V.; Saleem, S.; Husain, A. A novel polyherbal formulation containing thymoquinone attenuates carbon tetrachloride-induced hepatorenal injury in a rat model. Asian Pac. J. Trop. Biomed. 2020, 10, 147-155. [CrossRef]

266. Burmasova, M.A.; Utebaeva, A.A.; Sysoeva, E.V.; Sysoeva, M.A. Melanins of Inonotus obliquus: Bifidogenic and antioxidant properties. Biomolecules 2019, 9, 248. [CrossRef] [PubMed]

267. Egwim, E.; Elem, R. Proximate composition, phytochemical screening and antioxidant activity of ten selected wild edible Nigerian mushrooms. Am. J. Food Nutr. 2011, 1, 89-94. [CrossRef]

268. Vieira, V.; Barros, L.; Martins, A.; Ferreira, I.C.F.R. Expanding current knowledge on the chemical composition and antioxidant activity of the genus Lactarius. Molecules 2014, 19, 20650-20663. [CrossRef]

269. Rosa, G.B.; Sganzerla, W.G.; Ferreira, A.L.A.; Xavier, L.O.; Veloso, N.C.; da Silva, J.; de Oliveira, G.P.; Amaral, N.C.; de Veeck, A.P.L.; Ferrareze, J.P. Investigation of nutritional composition, antioxidant compounds, and antimicrobial activity of wild culinarymedicinal mushrooms Boletus edulis and Lactarius deliciosus (Agaricomycetes) from Brazil. Int. J. Med. Mushrooms 2020, 22, 931-942. [CrossRef] [PubMed]

270. Bozdogan, A.; Ulukanli, Z.; Bozok, F.; Eker, T.; Dogan, H.H.; Buyukalaca, S. Antioxidant potential of Lactarius deliciosus and Pleurotus ostreatus from amanos mountains. Adv. Life Sci. 2018, 5, 113-120.

271. Xu, Z.; Fu, L.; Feng, S.; Yuan, M.; Huang, Y.; Liao, J.; Zhou, L.; Yang, H.; Ding, C. Chemical composition, antioxidant and antihyperglycemic activities of the wild Lactarius deliciosus from China. Molecules 2019, 24, 1357. [CrossRef] [PubMed]

272. Fogarasi, M.; Diaconeasa, Z.M.; Pop, C.R.; Fogarasi, S.; Semeniuc, C.A.; Fărcaş, A.C.; TTibulcă, D.; Sălăgean, C.-D.; Tofană, M.; Socaci, S.A. Elemental composition, antioxidant and antibacterial properties of some wild edible mushrooms from Romania. Agronomy 2020, 10, 1972. [CrossRef]

273. Athanasakis, G.; Aligiannis, N.; Gonou-Zagou, Z.; Skaltsounis, A.L.; Fokialakis, N. Antioxidant properties of the wild edible mushroom Lactarius salmonicolor. J. Med. Food 2013, 16, 760-764. [CrossRef]

274. Zavastin, D.E.; Miron, A.; Gherman, S.P.; Boerescu, C.M.; Breaban, I.G.; Gavrilescu, C.M. Antioxidant activity, total phenolic and metals contents of Lactarius salmonicolor (R. HEIM \& LECLAIR). Farmacia 2015, 63, 755-759.

275. Chen, J.; Liu, D.; Liu, L.; Liu, P.; Xu, Q.; Xia, L.; Ling, Y.; Huang, D.; Song, S.; Zhang, D.; et al. A pilot study of hydroxychloroquine in treatment of patients with moderate COVID-19. Zhejiang Da Xue Xue Bao Yi Xue Ban 2020, 49, 215-229.

276. Garcia, J.; Afonso, A.; Fernandes, C.; Nunes, F.M.; Marques, G.; Saavedra, M.J. Comparative antioxidant and antimicrobial properties of Lentinula edodes Donko and Koshin varieties against priority multidrug-resistant pathogens. S. Afr. J. Chem. Eng. 2021, 35, 98-106.

277. Garcia, I.M.; S., A.R.; Montero, D.; Arellano, M. Evaluation of total polyphenols and antioxidant capacity in mushroom extracts Pleurotus ostreatus and Lentinula edodes. Int. J. Curr. Pharm. Res. 2020, 12, 96-99. [CrossRef]

278. Pinto, S.; Barros, L.; Sousa, M.J.; Ferreira, I.C.F.R. Chemical characterization and antioxidant properties of Lepista nuda fruiting bodies and mycelia obtained by in vitro culture: Effects of collection habitat and culture media. Food Res. Int. 2013, 51, 496-502. [CrossRef]

279. Shu, X.; Zhang, Y.; Jia, J.; Ren, X.; Wang, Y. Extraction, purification and properties of water-soluble polysaccharides from mushroom Lepista nuda. Int. J. Biol. Macromol. 2019, 128, 858-869. [CrossRef] [PubMed]

280. Du, J.; Guo, H.B.; Li, Q.; Forsythe, A.; Chen, X.H.; Yu, X.D. Genetic diversity of Lepista nuda (Agaricales, Basidiomycota) in Northeast China as indicated by SRAP and ISSR markers. PLoS ONE 2018, 13, e0202761. [CrossRef]

281. Mercan, N.; Duru, M.E.; Turko Glu, A.; Gezer, K.; Kivrak, I.; Turko Glu, H. Antioxidant and antimicrobial properties of ethanolic extract from Lepista nuda (Bull.) Cooke. Ann. Microbiol. 2006, 56, 339-344. [CrossRef]

282. Niu, L.L.; Wu, Y.R.; Liu, H.P.; Wang, Q.; Li, M.Y.; Jia, Q. Optimization of extraction process, characterization and antioxidant activities of polysaccharide from Leucopaxillus giganteus. J. Food Meas. Charact. 2021, 15, 2842-2853. [CrossRef]

283. Erbiai, E.H.; Pinto da Silva, L.; Saidi, R.; Lamrani, Z.; Esteves da Silva, J.C.G.; Maouni, A. Chemical composition, bioactive compounds and antioxidant activity of two wild edible mushrooms Armillaria mellea and Macrolepiota procera from two countries (Morocco and Portugal). Biomolecules 2021, 11, 575. [CrossRef]

284. Ramesh, C.; Pattar, M.G. Antimicrobial properties, antioxidant activity and bioactive compounds from six wild edible mushrooms of western ghats of Karnataka, India. Pharmacogn. Res. 2010, 2, 107-112.

285. Queirós, B.; Barreira, J.C.M.; Sarmento, A.C.; Ferreira, I.C.F.R. In search of synergistic effects in antioxidant capacity of combined edible mushrooms. Int. J. Food Sci. Nutr. 2009, 60, 160-172. [CrossRef] [PubMed]

286. Stojković, D.S.; Kovačević-Grujičić, N.; Reis, F.S.; Davidović, S.; Barros, L.; Popović, J.; Petrović, I.; Pavić, A.; Glamočlija, J.; Ćirić, A.; et al. Chemical composition of the mushroom Meripilus giganteus Karst. and bioactive properties of its methanolic extract. LWT Food Sci. Technol. 2017, 79, 454-462. [CrossRef] 
287. Maity, P.; Nandi, A.K.; Manna, D.K.; Pattanayak, M.; Sen, I.K.; Bhanja, S.K.; Samanta, S.; Panda, B.C.; Paloi, S.; Acharya, K.; et al. Structural characterization and antioxidant activity of a glucan from Meripilus giganteus. Carbohydr. Polym. 2017, 157, $1237-1245$. [CrossRef]

288. Sárközy, A.; Béni, Z.; Dékány, M.; Zomborszki, Z.P.; Rudolf, K.; Papp, V.; Hohmann, J.; Ványolós, A. Cerebrosides and steroids from the edible mushroom Meripilus giganteus with antioxidant potential. Molecules 2020, 25, 1395. [CrossRef]

289. Zhang, H.N.; Ma, H.L.; Zhou, C.S.; Yan, Y.; Yin, X.L.; Yan, J.K. Enhanced production and antioxidant activity of endopolysaccharides from Phellinus igniarius mutants screened by low power He-Ne laser and ultraviolet induction. Bioact. Carbohydr. Diet. Fibre 2018, 15, 30-36. [CrossRef]

290. Guo, J.; Liu, X.; Li, Y.; Ji, H.; Liu, C.; Zhou, L.; Huang, Y.; Bai, C.; Jiang, Z.; Wu, X. Screening for proteins related to the biosynthesis of hispidin and its derivatives in Phellinus igniarius using iTRAQ proteomic analysis. BMC Microbiol. 2021, 21, 1-16. [CrossRef]

291. Yan, J.K.; Wang, Y.Y.; Ma, H.L.; Wang, Z. Bin Ultrasonic effects on the degradation kinetics, preliminary characterization and antioxidant activities of polysaccharides from Phellinus linteus mycelia. Ultrason. Sonochem. 2016, 29, 251-257. [CrossRef]

292. Wu, J.J.; Zhu, Y.F.; Guo, Z.Z.; Lou, Y.M.; He, S.G.; Guan, Y.; Zhu, L.J.; Liu, Z.Q.; Lu, L.L.; Liu, L. Aconitum alkaloids, the major components of Aconitum species, affect expression of multidrug resistance-associated protein 2 and breast cancer resistance protein by activating the Nrf2-mediated signalling pathway. Phytomedicine 2018, 44, 87-97. [CrossRef]

293. Rahimah, S.B.; Djunaedi, D.D.; Soeroto, A.Y.; Bisri, T. The phytochemical screening, total phenolic contents and antioxidant activities in vitro of white oyster mushroom (Pleurotus ostreatus) preparations. Open Access Maced. J. Med. Sci. 2019, 7, $2404-2412$. [CrossRef]

294. Bakir, T.; Karadeniz, M.; Unal, S. Investigation of antioxidant activities of Pleurotus ostreatus stored at different temperatures. Food Sci. Nutr. 2018, 6, 1040-1044. [CrossRef]

295. Nguyen, T.K.; Im, K.H.; Choi, J.; Shin, P.G.; Lee, T.S. Evaluation of antioxidant, anti-cholinesterase, and anti-inflammatory effects of culinary mushroom Pleurotus pulmonarius. Mycobiology 2016, 44, 291-301. [CrossRef]

296. Contato, A.G.; Inácio, F.D.; de Araújo, C.A.V.; Brugnari, T.; Maciel, G.M.; Haminiuk, C.W.I.; Bracht, A.; Peralta, R.M.; de Souza, C.G.M. Comparison between the aqueous extracts of mycelium and basidioma of the edible mushroom Pleurotus pulmonarius: Chemical composition and antioxidant analysis. J. Food Meas. Charact. 2020, 14, 830-837. [CrossRef]

297. Gambato, G.; Todescato, K.; Pavão, E.M.; Scortegagna, A.; Fontana, R.C.; Salvador, M.; Camassola, M. Evaluation of productivity and antioxidant profile of solid-state cultivated macrofungi Pleurotus albidus and Pycnoporus sanguineus. Bioresour. Technol. 2016, 207, 46-51. [CrossRef] [PubMed]

298. Cao, J.; Zhang, H.J.; Xu, C.P. Culture characterization of exopolysaccharides with antioxidant activity produced by Pycnoporus sanguineus in stirred-tank and airlift reactors. J. Taiwan Inst. Chem. Eng. 2014, 45, 2075-2080. [CrossRef]

299. Bhanja, S.K.; Samanta, S.K.; Mondal, B.; Jana, S.; Ray, J.; Pandey, A.; Tripathy, T. Green synthesis of Ag@Au bimetallic composite nanoparticles using a polysaccharide extracted from Ramaria botrytis mushroom and performance in catalytic reduction of 4-nitrophenol and antioxidant, antibacterial activity. Environ. Nanotechnol. Monit. Manag. 2020, 14, 100341. [CrossRef]

300. Han, S.R.; Kim, K.H.; Kim, H.J.; Jeong, S.H.; Oh, T.J. Comparison of biological activities using several solvent extracts from Ramaria botrytis. Indian J. Sci. Technol. 2016, 9, 1-6. [CrossRef]

301. Li, H. Extraction, purification, characterization and antioxidant activities of polysaccharides from Ramaria botrytis (Pers.) Ricken. Chem. Cent. J. 2017, 11, 1-9. [CrossRef]

302. He, T.; Yan, S.F.; Chen, J. Structure and antioxidant activity of HAP-I in Russula vinosa. Mod. Food Sci. Technol. $2015,31,63-68$.

303. Liu, Q.; Tian, G.; Yan, H.; Geng, X.; Cao, Q.; Wang, H.; Ng, T.B. Characterization of polysaccharides with antioxidant and hepatoprotective activities from the wild edible mushroom Russula vinosa lindblad. J. Agric. Food Chem. 2014, 62, 8858-8866. [CrossRef]

304. Abd Razak, D.L.; Mohd Fadzil, N.H.; Jamaluddin, A.; Abd Rashid, N.Y.; Sani, N.A.; Abdul Manan, M. Effects of different extracting conditions on anti-tyrosinase and antioxidant activities of Schizophyllum commune fruit bodies. Biocatal. Agric. Biotechnol. 2019, 19, 101116. [CrossRef]

305. Wanna, C.; Sudhadham, M. The effect of coconut water and boiling on antioxidant activity and total phenolic contents in Schizophyllum commune Fr. Pharmacogn. J. 2018, 10, 925-931. [CrossRef]

306. Basso, V.; Schiavenin, C.; Mendonça, S.; de Siqueira, F.G.; Salvador, M.; Camassola, M. Chemical features and antioxidant profile by Schizophyllum commune produced on different agroindustrial wastes and byproducts of biodiesel production. Food Chem. 2020, 329, 127089. [CrossRef] [PubMed]

307. Ngoc, L.T.N.; Oh, Y.K.; Lee, Y.J.; Lee, Y.C. Effects of sparassis crispa in medical therapeutics: A systematic review and meta-analysis of randomized controlled trials. Int. J. Mol. Sci. 2018, 19, 1487. [CrossRef] [PubMed]

308. Nitha, B.; Fijesh, P.V.; Janardhanan, K.K. Hepatoprotective activity of cultured mycelium of Morel mushroom, Morchella esculenta. Exp. Toxicol. Pathol. 2013, 65, 105-112. [CrossRef]

309. Wu, X.; Zeng, J.; Hu, J.; Liao, Q.; Zhou, R.; Zhang, P.; Chen, Z. Hepatoprotective effects of aqueous extract from lingzhi or reishi medicinal mushroom Ganoderma lucidum (Higher Basidiomycetes) on $\alpha$-amanitin-induced liver injury in mice. Int. J. Med. Mushrooms 2013, 15, 383-391. [CrossRef]

310. Liu, Q.; Zhu, M.; Geng, X.; Wang, H.; Ng, T.B. Characterization of polysaccharides with antioxidant and hepatoprotective activities from the edible mushroom Oudemansiella radicata. Molecules 2017, 22, 234. [CrossRef] [PubMed] 
311. Nisar, J.; Mustafa, I.; Anwar, H.; Sohail, M.U.; Hussain, G.; Ullah, M.I.; Faisal, M.N.; Bukhari, S.A.; Basit, A. Shiitake culinarymedicinal mushroom, Lentinus edodes (Agaricomycetes): A species with antioxidant, immunomodulatory, and hepatoprotective activities in hypercholesterolemic rats. Int. J. Med. Mushrooms 2017, 19,981-990. [CrossRef]

312. Chang, C.W.; Lur, H.S.; Lu, M.K.; Cheng, J.J. Sulfated polysaccharides of Armillariella mellea and their anti-inflammatory activities via NF-кB suppression. Food Res. Int. 2013, 54, 239-245. [CrossRef]

313. Talero, E.; Avila-Roman, J.; Motilva, V. Chemoprevention with phytonutrients and microalgae products in chronic inflammation and colon cancer. Curr. Pharm. Des. 2012, 18, 3939-3965. [CrossRef]

314. Chien, R.C.; Lin, L.M.; Chang, Y.H.; Lin, Y.C.; Wu, P.H.; Asatiani, M.D.; Wasser, S.G.; Krakhmalnyi, M.; Agbarya, A.; Wasser, S.P.; et al. Anti-inflammation properties of fruiting bodies and submerged cultured mycelia of culinary-medicinal higher basidiomycetes mushrooms. Int. J. Med. Mushrooms 2016, 18, 999-1009. [CrossRef]

315. Yuan, B.; Zhao, L.; Rakariyatham, K.; Han, Y.; Gao, Z.; Muinde Kimatu, B.; Hu, Q.; Xiao, H. Isolation of a novel bioactive protein from an edible mushroom Pleurotus eryngii and its anti-inflammatory potential. Food Funct. 2017, 8, 2175-2183. [CrossRef]

316. Liu, T.; Jiang, X.; Wang, W.; Xu, B. Optimization, characterization and antioxidant activities of selenized polysaccharides from Hypsizygus marmoreus. Am. J. Biochem. Biotechnol. 2019, 15, 138-149. [CrossRef]

317. Ahn, W.S.; Kim, D.J.; Chae, G.T.; Lee, J.M.; Bae, S.M.; Sin, J.I.; Kim, Y.W.; Namkoong, S.E.; Lee, I.P. Natural killer cell activity and quality of life were improved by consumption of a mushroom extract, Agaricus blazei Murill Kyowa, in gynecological cancer patients undergoing chemotherapy. Int. J. Gynecol. Cancer 2004, 14, 589-594. [CrossRef] [PubMed]

318. Therkelsen, S.P.; Hetland, G.; Lyberg, T.; Lygren, I.; Johnson, E. Cytokine levels after consumption of a medicinal Agaricus blazei Murill-based mushroom extract, AndoSan ${ }^{\mathrm{TM}}$, in patients with Crohn's disease and ulcerative colitis in a randomized single-blinded Placebo-controlled study. Scand. J. Immunol. 2016, 84, 323-331. [CrossRef] [PubMed]

319. Hess, J.M.; Wang, Q.; Kraft, C.; Slavin, J.L. Impact of Agaricus bisporus mushroom consumption on satiety and food intake. Appetite 2017, 117, 179-185. [CrossRef] [PubMed]

320. Hess, J.; Wang, Q.; Gould, T.; Slavin, J. Impact of Agaricus bisporus mushroom consumption on gut health markers in healthy adults. Nutrients 2018, 10, 1402. [CrossRef] [PubMed]

321. Ba, D.M.; Gao, X.; Muscat, J.; Al-Shaar, L.; Chinchilli, V.; Zhang, X.; Ssentongo, P.; Beelman, R.B.; Richie, J.P. Association of mushroom consumption with all-cause and cause-specific mortality among American adults: Prospective cohort study findings from NHANES III. Nutr. J. 2021, 20, 38. [CrossRef]

322. Li, J.; Zou, L.; Chen, W.; Zhu, B.; Shen, N.; Ke, J.; Lou, J.; Song, R.; Zhong, R.; Miao, X. Dietary mushroom intake may reduce the risk of breast cancer: Evidence from a meta-analysis of observational studies. PLoS ONE 2014, 9, e93437. [CrossRef] [PubMed]

323. Dai, X.; Stanilka, J.M.; Rowe, C.A.; Esteves, E.A.; Nieves, C., Jr.; Spaiser, S.J.; Christman, M.C.; Langkamp-Henken, B.; Percival, S.S. Immune Benefits from Mushroom Consumption. (20 July 2011-30 December 2013). Identifier NCT01398176. Available online: https: / / clinicaltrials.gov/ct2/show / NCT01398176 (accessed on 27 August 2021).

324. Dai, X.; Stanilka, J.M.; Rowe, C.A.; Esteves, E.A.; Nieves, C., Jr.; Spaiser, S.J.; Christman, M.C.; Langkamp-Henken, B.; Percival, S.S. Consuming Lentinula edodes (Shiitake) mushrooms daily improves human immunity: A randomized dietary intervention in healthy young adults. J. Am. Coll. Nutr. 2015, 34, 478-487. [CrossRef]

325. Wesa, K.M.; Cunningham-Rundles, S.; Klimek, V.M.; Vertosick, E.; Coleton, M.I.; Yeung, K.S.; Lin, H.; Nimer, S.; Cassileth, B.R. Does Maitake Mushroom Extract Enhance Hematopoiesis in Myelodysplastic Patients? (8 April 2010-19 May 2016). Identifier NCT01099917. Available online: https:/ / clinicaltrials.gov/ct2/show/NCT01099917 (accessed on 27 August 2021).

326. Wesa, K.M.; Cunningham-Rundles, S.; Klimek, V.M.; Vertosick, E.; Coleton, M.I.; Yeung, K.S.; Lin, H.; Nimer, S.; Cassileth, B.R. Maitake mushroom extract in myelodysplastic syndromes (MDS): A phase II study. Cancer Immunol. Immunother. 2015, 64, 237-247. [CrossRef] [PubMed]

327. Kelly, C.P. Effects of Pre-, Pro- \& Anti-Biotics on Gut Microbiota. (11 August 2011-24 July 2017). Identifier NCT01414010. Available online: https: / / clinicaltrials.gov/ct2/show / results/NCT01414010 (accessed on 27 August 2021).

328. Chae, S.-W. A 12-week Human Trial to Compare the Efficacy and Safety of Polycan on Bone Metabolism. (26 July 2011-12 October 2012). Identifier NCT01402115. Available online: https: / clinicaltrials.gov / ct2/show / results / NCT01402115 (accessed on 27 August 2021).

329. Griffiths, R.R.; Johnson, M.W.; Carducci, M.A.; Umbricht, A.; Richards, W.A.; Richards, B.D.; Cosimano, M.P.; Klinedinst, M.A. Psychopharmacology of Psilocybin in Cancer Patients. (25 April 2007-19 July 2018). Identifier NCT00465595. Available online: https: / / www.clinicaltrials.gov / ct2/show / NCT00465595 (accessed on 27 August 2021).

330. Griffiths, R.R.; Johnson, M.W.; Carducci, M.A.; Umbricht, A.; Richards, W.A.; Richards, B.D.; Cosimano, M.P.; Klinedinst, M.A. Psilocybin produces substantial and sustained decreases in depression and anxiety in patients with life-threatening cancer: A randomized double-blind trial. J. Psychopharmacol. 2016, 30, 1181-1197. [CrossRef] [PubMed]

331. Lopes, L.C. Effects of Lentinula edodes Bars on Dyslipidemia and Oxidative Stress in Cholesterol Individuals: Randomized Study. (5 December 2019-27 October 2020). Identifier NCT04186780. Available online: https://clinicaltrials.gov/ct2/show/study/ NCT04186780 (accessed on 27 August 2021). 